\title{
Policies, actors and sustainability transition pathways: A study of the EU's energy policy mix
}

\section{Marie Byskov Lindberga, Jochen Markardb, Allan Dahl Andersena}

\author{
a TIK Centre for Innovation, Technology and Culture, \\ University of Oslo (UiO) \\ b Group for Sustainability and Technology, \\ Swiss Federal Institute of Technology Zurich (ETH Zurich)
}

\begin{abstract}
Policies and politics are crucial elements of sustainability transitions. Transition pathways unfold as a result of continuous struggles of actors over policy goals and instruments. Taking a policy mix perspective, we study policies and policy preferences of key industry actors in the ongoing energy transition at the level of the European Union. We introduce two central analytical dimensions for transition pathways: the degree of sustainability (here: renewable energy ambition) and the degree of disruption (here: whether to pursue centralized or decentralized energy system configurations). We find that the current EU energy policy mix is heterogeneous with respect to the issue of (de-)centralization, whereas most policies and actors express high or moderate ambitions for renewable energy. Our paper makes three contributions. It demonstrates how actors and policy preferences can be explicitly included in the study of policy mixes. To the literature on transition pathways, we introduce sustainability as another key dimension in addition to disruption. Lastly, we propose a novel methodology for analyzing the politics of transition pathways.
\end{abstract}

\section{Keywords}

Sustainability transitions; policy mix; transition pathways; actor preferences; energy policy; European Union

\section{Highlights}

- We study the politics of sustainability transition pathways in EU energy policy.

- To policy mix studies we add an assessment of industry actors' policy preferences.

- We study how policies and actor preferences relate to future transition pathways.

- We find that renewables and decentralization are major conflict lines.

- The EU policy mix contains strong centralizing and some decentralizing elements. 


\section{Introduction}

Sustainability issues such as climate change, degradation of ecosystems, depletion of natural resources or lack of clean water and sanitation pose extraordinary challenges for societies (UNEP, 2016). Many of these problems have a global dimension, confront present and future generations and are very difficult to solve (Reid et al., 2010). In fact, they may require fundamental changes in consumption practices, lifestyles, technologies, infrastructures, business models and policies.

Against this background, sustainability transitions in which entire sectors such as energy, food or transport change fundamentally have received increasing attention (Markard et al., 2012). One of the core themes in sustainability transitions research is the role of public policies in transition processes (Alkemade et al., 2011; Haley, 2017; Jacobsson and Bergek, 2011; Kemp and Loorbach, 2006). Policies formulate long-term sustainability targets, request emission reductions, provide R\&D funding or grant market support for new technologies (e.g. wind or solar). In fact, sustainability transitions are affected by many different policies at the same time.

To capture the variety and potential interaction of different policies as well as ongoing changes in policies, scholars have suggested studying policy mixes for sustainability transitions (Kivimaa and Kern, 2016; Rogge and Reichardt, 2016). The policy mix perspective does not only highlight the interplay of different policies but also points to the contested and messy nature of the policy process (Flanagan et al., 2011), including the importance of politics with different actors pursuing different interests (Lauber and Jacobsson, 2016; Raven et al., 2016).

From a transitions perspective, changes in policies, or policy mixes, and changes in socio-technical systems are highly interdependent (Edmondson et al., this issue; Markard et al., 2016). Policies can support and protect niche innovations (e.g. R\&D programs, deployment subsidies) or constrain incumbent technologies (e.g. emissions performance standards, fuel taxes). The resulting changes in the sociotechnical system will then again lead to amendments in the policy mix. In fact, transitions can follow different pathways, and these pathways are shaped by policies and by the strategies of the actors involved (Geels et al., 2016; Geels and Schot, 2007; Smith et al., 2005).

This paper studies the politics of sustainability transition pathways and takes a particular interest in how policies and actors influence the direction of a transition. We ask which policies and which actors favor which kind of pathway and suggest a methodological approach to analyze major conflict lines in an ongoing transition. We introduce two generic dimensions to analyze the politics of sustainability transition pathways. These are the degree of sustainability and the degree of disruption. 
Both dimensions capture the struggles and potential conflicts of actors over different directions of development. The first dimension is about whether actors or policies are more or less ambitious in the promotion of environmental sustainability, while the latter analyses whether actors or policies target more or less disruptive system change. The sustainability dimension reflects struggles over values and is obviously at the core of sustainability transitions. The second dimension reflects material struggles over existing assets and infrastructure, business models, competences etc. It is particularly relevant from an actor perspective because more disruptive pathways are particularly threatening for incumbent players and existing businesses.

Our analysis consists of two parts, an analysis of the policy mix and an analysis of industry actors' policy preferences. We use the above dimensions to connect both parts. Through the dimensions we map the potential impact of the current policies as well as the preferences of central actors. Thereby, we do not only understand who benefits from the ongoing transition but we also gain insights into the policy process ${ }^{1}$, i.e. who supports which aspects of future policies.

Our empirical field is the electricity sector. It is currently experiencing a fundamental transformation ${ }^{2}$ and perhaps the most prominent, contemporary example of a sustainability transition (Laes et al., 2014; Markard, 2018). Our scope of analysis is the European Union and EU level policies. In terms of actors, we focus on major industry actors, including associations, large firms and environmental organizations.

Our paper makes three contributions. The first is to strengthen the analysis of actors in combination with a study of the policy mix. Even though the policy mix perspective emphasizes the policy process and strategic maneuvering of actors, existing studies have concentrated on policies rather than actors. This is clearly a gap, as actors mobilize a variety of strategies to influence the policy process (Gullberg, 2013; Hess, 2014; Lauber and Jacobsson, 2016). With our focus on actor preferences we can analyze whether policy mix and actor preferences overlap or diverge. In addition, we can identify common interests as well as conflict lines among different groups of actors.

The second contribution is an analysis of transition pathways with a focus on the underlying politics. Our two dimensions reflect that there are struggles over values and societal norms (sustainability), as well as struggles over material interests,

1 Note that this study primarily looks at industry actors. The understanding of the entire policy process, which also involves formal policy makers such as parties and state actors, therefore has to remain limited.

2 We will refer to the transformation of the electricity sector as 'energy transition' in the following. 
which are particularly prominent if a pathway is disruptive and significantly departs from the current state of the socio-technical system. While the degree of disruption builds on existing conceptualizations of socio-technical transition pathways (Geels et al., 2016; Geels and Schot, 2007), sustainability directs attention to the fact that - in the case of sustainability transitions - there are additional political conflicts over societal values (Schlaile et al., 2017)

Our third contribution is a methodological one. We suggest a novel approach to systematically analyze and compare policies and actor preferences by means of categorical variables and a coding system, which enables a quantitative representation of the qualitative analysis. We use the generic dimensions to systematically capture key characteristics of an unfolding transition.

\section{Theoretical background}

Our paper is positioned in the literature on sustainability transitions and makes specific contributions to research on policy mixes and transition pathways. This is what we introduce below. The paper also speaks to existing studies on lobbying and policy processes at the EU level. Some of these will be referred to and discussed in section 3.2.

A key characteristic of sustainability transitions is that they are associated with long-term sustainability targets, which may be formulated in public policies or policy programs. As a consequence, public policies typically play a central role for sustainability transitions - as they convey transition targets (Reichardt and Rogge, 2016), provide R\&D funding (Alkemade et al., 2011; Haley, 2017), define environmental standards (Girod, 2016), grant support for specific technologies (Jacobsson and Bergek, 2011; Verbruggen and Lauber, 2012), phase-out unwanted technologies such as nuclear power (Wittneben, 2012), or even guide transition processes (Kemp and Loorbach, 2006).

Another characteristic of sustainability transitions is that they are inherently value laden and contested (Schlaile et al., 2017; Smith and Stirling, 2010). As a consequence, there is a central role for politics, i.e. different kinds of actors influencing the process of policy making in pursuit of their interests (Lauber and Jacobsson, 2016; Markard et al., 2016; Meadowcroft, 2011; Stirling, 2014). Actors deploy a broad range of strategies to influence the policy process, including lobbying (Fagan-Watson et al., 2015; Gullberg, 2013; Meckling, 2011), donations to political campaigns (Hess, 2014), or shaping public discourses (Geels and Verhees, 2011; Konrad et al., 2012). Through these kinds of activities actors influence and shape socio-technical pathways. 


\subsection{Policy mix}

To account for the multiplicity and complex interplay of policies in sustainability transitions, scholars have suggested taking a policy mix perspective (Rogge and Reichardt, 2016). The term policy mix mainly refers to a combination of different policy instruments and their interaction (Flanagan et al., 2011; Kivimaa and Kern, 2016). As a conceptual extension, Rogge and Reichardt (2016) developed a more holistic policy mix framework building on insights from political sciences. It goes beyond the focus on instruments as it also includes policy plans and objectives (referred to as 'policy strategy'). And it goes beyond policies as it also embraces the policy process, consisting of policy making and implementation. ${ }^{3}$

Several empirical studies have been carried out in recent years addressing policy mixes for sustainability transitions. For example, Kivimaa and Virkamäki (2014) study which policy instruments hinder or support a transition to low-carbon transportation in Finland, while Kivimaa and Kern (2016) present findings from a comparative study on energy efficiency policies in the UK and Finland. They argue that, for sustainability transitions, policies also have to support processes of regime destabilization and suggest specific functions for destruction.

Interestingly, the analysis of policies is still very much at the core of most of the existing studies, despite the ambition to include politics and to take a closer look at actors (Rogge and Reichardt, 2016). A noteworthy exception is the study by Reichardt et al. (2016), which shows the potential of studying the complex interplay of actors, innovation activities, and policy changes. Embracing this complexity is also a key argument of Flanagan et al. (2011) who criticize simplified, de-contextualized perspectives on the policy mix. They emphasize the conflicts that necessarily arise when policies targeting the same actors are formulated at different times, with different objectives, by different actors, and at different governance levels. Consequently, the authors ask to "highlight the trade-offs and tensions inherent in any policy mix" rather than to follow unrealistic normative ideals of effective, well-coordinated policy mixes (Flanagan et al., 2011, p. 711).

This paper complements existing policy mix studies by introducing an in-depth focus on actors. It combines the assessment of policies with an analysis of the policy preferences of actors. In our empirical study, we focus on firms and interest organizations as they are affected by policies and, at the same time, seek to influence policy making. However, our method is not limited to these players and

${ }^{3}$ The various extensions make the framework highly comprehensive. Here, we have to limit ourselves to some of the suggestions. We study policy instruments and strategies and with our analysis of actor preferences we also take a (limited) look at the policy process. 
other types of actors (e.g. those formally involved in policy making) can be included as well.

Combining the analysis of policies and actor preferences generates several benefits. First, actor preferences provide tentative insights into ongoing policy processes and reveal main conflict lines. Second, the analysis informs us more generally on who benefits (or not) from specific socio-technical pathways, thereby shedding light on the transition more broadly. Third, it enables us to investigate which policy preferences vary strongly across actors and whether there are certain groups of actors, which hold similar positions. This may point to potential coalitions of actors working toward common policy goals (Markard et al., 2016).

\subsection{Transition pathways}

A transition pathway can be viewed as a semi-coherent pattern of major changes in the configuration of a socio-technical system subject to continual processes of political contestation (Rosenbloom, 2017). Research on socio-technical transition pathways has been sparked by the recognition that transitions are context dependent and unfold very differently under different circumstances (Foxon, 2013; Geels and Schot, 2007; Hansen and Coenen, 2015; Smith et al., 2005).

In some cases, a sector transforms gradually, step-by-step and incumbent actors are able to maintain their positions and roles, albeit adapting key technologies or business models. Examples include continuous performance improvements in core technologies such as gas turbines (Bergek et al., 2013), the uptake of process innovations such as digitalization in supply chain management (Dolata, 2009), or incumbent driven innovation in the lighting industry (Franceschini and Alkemade, 2016). In other cases, sector structures change in a more chaotic and unplanned way, involving the substitution of key technologies and an erosion of incumbents' market positions. Examples include the transition from carriages to automobiles (Geels, 2005), the disruption of the music industry by digitalization (Dolata, 2009) or, potentially, decentralized generation in electricity (Hess, 2015).

A central theme in the literature on transition pathways is the degree to which novel innovations are radical or disruptive and the impact this has on how transitions unfold (Dahlin and Behrens, 2005; Dijk et al., 2016; Dolata, 2009; Geels and Schot, 2007). In the pathway typology of Geels and Schot (2007), the nature of interaction between niche, regime and landscape dynamics and whether niches or landscape pressures are disruptive or not, plays a central role. Studies also found that transition pathways which involve a high degree of disruptive change will be more contested (Geels et al., 2016).

In fact, we know from the transitions literature that incumbent actors often seek to resist or slow down an ongoing transition because it threatens their assets, 
competences and business models (Kungl, 2015; Lauber and Jacobsson, 2016; Smink et al., 2015). Incumbents also tend to favor policies, and transition pathways, that are less disruptive (Markard et al., 2016). Consequently, they actively try to shape public policies in the favor of their interests (Hess, 2014; Wesseling et al., 2014). This underlines that degree of disruption to the sociotechnical system together with the study of incumbent industry actors is of central importance to understand the political struggles over transition pathways.

\subsection{Analytical framework}

In order to analyze the politics of transition pathways we use two dimensions that reflect the struggles and potential conflicts of actors (and policies) over different directions of the ongoing transformation. The first is the degree of environmental sustainability, which reflects normative conflicts in sustainability transitions (Leach et al., 2010; Stirling, 2014). We explore whether policies have higher or lower ambitions to pursue environmental targets and whether actors express stronger or weaker preferences for environmental issues. In the case of the electricity sector, we operationalize the degree of sustainability by more or less ambitious targets for renewable energies (see section 4).

The second is the degree of disruption. This dimension is about whether there will be more or less profound changes in the basic architecture of the socio-technical system. ${ }^{4}$ In terms of politics, this dimension reflects struggles over material interests. In our specific case, the degree of disruption will be operationalized by whether actors (and policies) pursue a more or less decentralized electricity system.

Both dimensions challenge incumbent industry actors. Disruption has strong implications for the competitiveness of existing businesses. It affects the value of organizational assets and competences, the viability of established business models, and potential advantages of new entrants etc. (Markard and Petersen, 2009; Richter, 2013; Stirling, 2014). Highly ambitious sustainability targets can also challenge incumbent firms, especially if they are invested in less sustainable production technologies. However, there may be sustainable alternatives that are well aligned with the competences and business models of established firms, and thus less disruptive. Examples of less-disruptive but more sustainable technologies in electricity include e.g. offshore wind or carbon capture and storage (see section 4.2).

\footnotetext{
${ }^{4}$ We assume that disruptions at the system or sectoral level also translate into disruptive changes for established firms and their business models. At the level of firms, we understand degree of disruption as the extent to which resources and competences are rendered obsolete.
} 
Against this background we argue that the degree of disruption and the degree of sustainability are sufficiently independent to distinguish different transition pathways as to whether actors and policies rank high on one or both dimensions, cf. Figure 1. Departing from a socio-technical system that is not sustainable (status quo), every transition includes changes compared to current practices. These changes, however, can be more or less sustainable and more or less disruptive for incumbent actors. The pathway leading to the upper left quadrant represents a less-disruptive sustainability transition. It generates major improvements in terms of sustainability but provides incumbent players with opportunities for redeploying core competences and for maintaining business models in a slightly moderated form (Berggren et al., 2015; Geels et al., 2016b; Mäkitie et al., 2018). The pathway leading to the upper right quadrant generates major sustainability improvements together with major changes in the configuration of the socio-technical system (highly disruptive for incumbents). A third pathway into the lower right quadrant would be a transition characterized by disruptive change without a major improvement in terms of sustainability.

Note that also the speed of change could be analyzed as a key dimension of sustainability transition pathways. It has implications for sustainability (how quickly improvements are achieved) as well as for disruption (how quickly established structures are overturned). We leave this for future studies to explore.

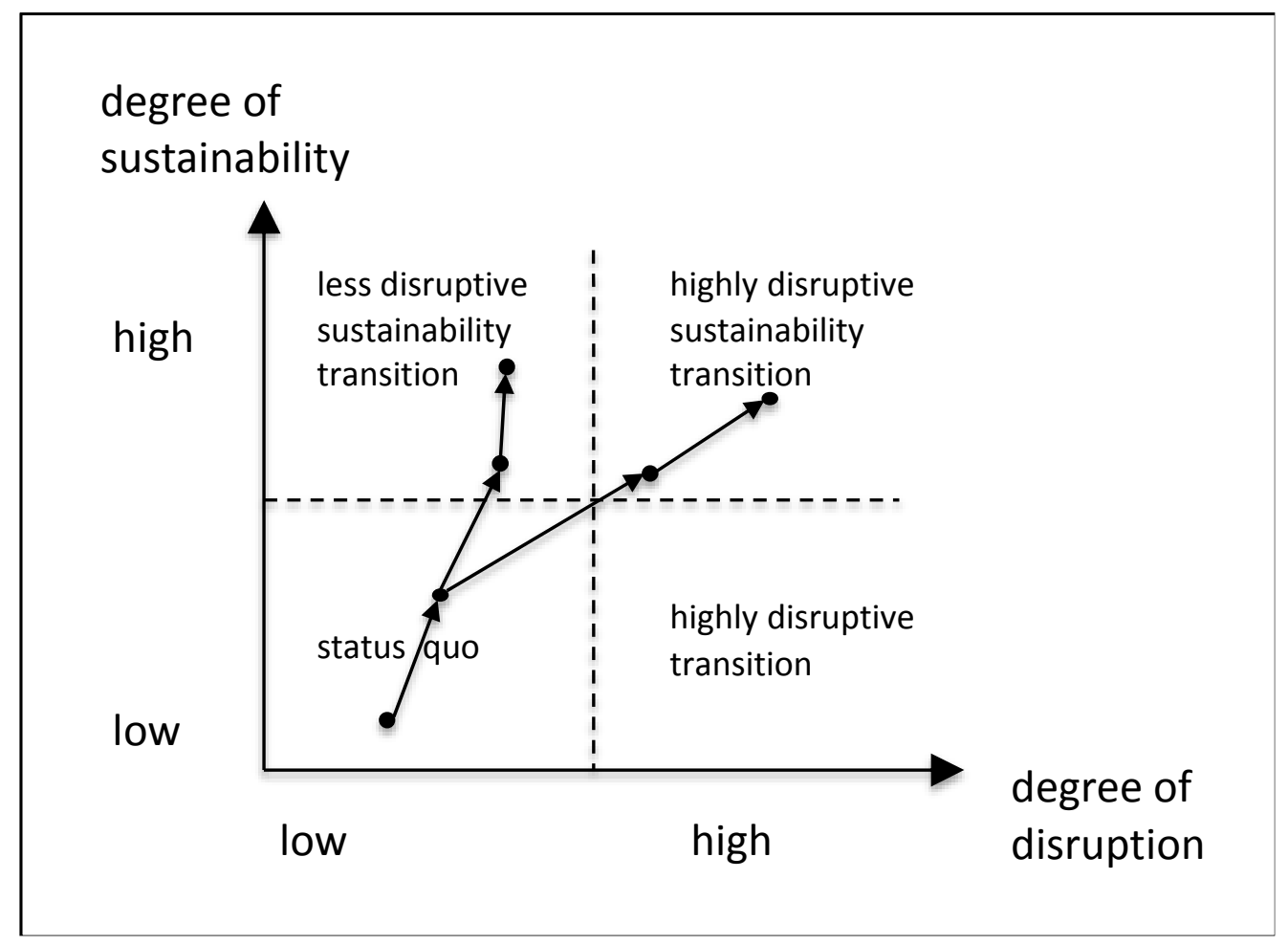

Figure 1: Dimensions to analyze the politics of transition pathways 
The overarching goal of our paper is to develop insights into the direction of an ongoing transition and shed light on the underlying politics. More specifically, we explore which policies support and which actors favor which kind of pathway.

In transition studies, scholars often work with three main analytical elements, or dimensions: actors, technologies and institutions (e.g. Geels, 2004). Accordingly, a transition can be conceptualized as a series of major, interdependent changes in each of these sets of elements. A transition pathway emerges as a result of these interrelated changes.

In this paper, we focus on policies and actors (cf. Figure 2). Policies are part of the institutional structures of a socio-technical system and our analysis of the policy mix also provides insights into the interaction of different policies. Actors are studied through their policy preferences, i.e. their views on policy goals, strategies, and instruments. Our understanding of policy preferences is similar to the concepts of secondary beliefs (Sabatier and Weible, 2007). We identify policy preferences in written statements that are submitted by the actors to public consultations, which are part of the policy making process (see section 3). As such, they reflect a confined part of the policy process and the politics associated with different transition pathways. We interpret these statements as expressions of the actors' interests.

In our study, the two dimensions of transition pathways connect the analysis of policies and the identification of actor preferences. From our data, we can compare how the current policy mix and recent actor preferences overlap or diverge. This can serve as an indication which actors prefer which policies. Moreover, we can identify conflict lines among different groups of actors, as well as tensions or inconsistencies between different policies. However, as our analyses of actors and policies overlap in time, we cannot establish a direct causal link between the two in our study.

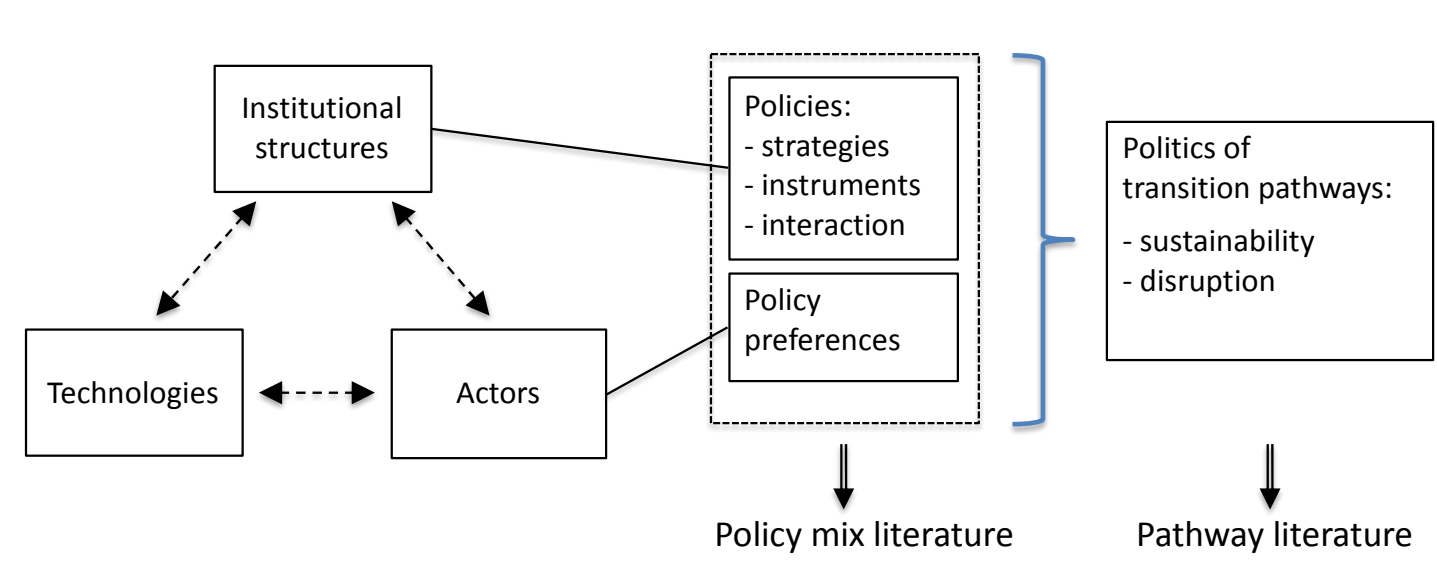

Generic transition dynamics

Focus of this paper 


\section{Figure 2: Analytical framework}

\section{EU energy policies and politics}

Our empirical field is the ongoing energy transition in the European Union (EU). The expansion of renewable energies and the reduction of greenhouse gas emissions are two key policy targets in this transformation, which is why we conceptualize it as a transition towards sustainability. At the same time, the transition is also driven by other goals than sustainability, such as increasing competitiveness and creating a common European energy market. In our study, we focus on the electricity sector.

The transition in EU electricity sector is an interesting case for several reasons. First, it is a purposive transition driven by a broad range of policies, which can be analyzed from a policy mix perspective. Second, the transition affects not just the sector itself but also many energy intensive industries, which means that there is a high degree of contestation and lobbying (Fagan-Watson et al., 2015; Ydersbond, 2016). Third, the EU energy transition has progressed fast in recent years with very successful deployment of renewable energies. Finally, the EU is in the process of formulating new policies, which will further shape the transition pathway. This offers a good opportunity to track preferences of key actors in the policy process.

\subsection{EU energy policy}

Since the 1980s, EU energy policy has pivoted around a drive to liberalize markets and to create an internal market for electricity and gas (Jamasb and Pollitt, 2005). The overall objective was to bring energy prices down and to improve the security of supply. Although the degree of liberalization and competition still varies across the EU, it is getting closer to the target of building an internal electricity market (Glachant and Ruester, 2014). Still, interconnector deployment has been slower than anticipated, which is why the European Council has called for speedy action to achieve the $10 \%$ interconnector target by 2020 (European Commission, 2015). ${ }^{5}$

Climate change is another important element of EU energy policy. It appeared as a new topic on the EU energy policy agenda during the 1990s with the adoption of the UN Framework Convention on Climate Change and the Kyoto Protocol (Görlach et al., 2017). A first major milestone was the launch of the EU emissions trading

5 The interconnection target of $10 \%$ means that each EU member state should have an import capacity corresponding to at least $10 \%$ of the country's installed electricity generation capacity. 
system (ETS) in 2005. In 2009, the EU adopted the Climate and Energy package for 2020, which included legislation on renewable energy, emissions trading and economy-wide targets for $2020^{6}$, combined with several directives and burden sharing measures between member states.

In parallel with these environmental policies, the EU adopted a Third Energy Package on market liberalization. Among other things, it sets rules for the unbundling of electricity companies and formulates a strong pan-European focus with provisions for cross-border power exchange.

In 2014, the 2030 Energy \& Climate policy framework was launched, formulating three key targets for 2030.7 In 2016, the EU Commission presented the "Clean Energy Package for All Europeans", which brings together several of the policies adopted in the Third Energy Package and in the Climate \& Energy Package.

\subsection{EU energy politics}

The impact of interest organizations on EU policy making takes many ways; through influencing the Commission, Member States' governments and Members of Parliament. Several studies have looked into EU energy politics. Here we share some of their insights to better illustrate the context our study is situated in.

Ydersbond (2016) assesses the influence of a broad variety of actors on the output of the policy process. She finds that the Commission, Eastern European member states, and incumbent industry actors had a high impact on the 2030 targets, which "green minded businesses", progressive energy companies and environmental NGOs viewed as a major disappointment (Ydersbond, 2016). FitchRoy (2017) studies the role of interest organizations in the process of the renewable energy target-setting in the EU 2030 energy- and climate framework. The study highlights the tradeoffs environmental NGOs were facing, when both the reform of the EU ETS and the formulation of new renewable energy targets for 2030 were negotiated at the same time. This is presented as one of the reasons why a relatively weaker renewable energy target was decided for 2030, compared to the earlier targets in the climate and energy framework ${ }^{8}$ (Fitch-Roy, 2017, p. 211). In

6 The 2020-targets include: 20\% greenhouse gas emissions reduction, 20\% renewable energy and $20 \%$ improvement in energy efficiency by 2020 .

$740 \%$ emissions reduction, 27\% renewable energy and $27 \%$ improvement in energy efficiency

8 A $27 \%$ RES target by 2030 is a weakening of ambition compared to the $20 \%$ target by 2020. Analyses by Agora Energiewende (2017) have shown that the target might be achieved without additional efforts. The Commission's impact assessment finds that with a business-as-usual development (the reference scenario), the renewable share in 2030 is $24.4 \%$. However, this target is still subject to strong negotiations, as it also 
a similar vein, Fagan-Watson et al. (2015) explore how a selection of eight trade associations such as BusinessEurope, CEPI, Eurelectric or Eurofer have lobbied on EU climate policy. The study finds that climate policy is a major concern for many firms and that they use associations as a primary means to represent their interests in EU policy making. The authors also raise the question whether associations might even undermine some of their members' interests, especially of those firms that see business opportunities in stricter emission guidelines.

These and several other studies (e.g. Boasson and Wettestad, 2013; Gullberg, 2013; Skjærseth et al., 2016) document that a variety of actors are involved in and influence EU energy policy making. A general finding is that influence of different stakeholders and institutions varies across issues and types of legislation at stake.

\section{Methods}

This section contains four parts. At first, we explain what data sources we used and how we selected relevant policies and actors. Then we describe how we adapted the two pathway dimensions to capture the specifics of the electricity sector. Next, we introduce the coding scheme to assess these two dimensions. Finally, we explain how we analyzed policies and the policy mix.

\subsection{Data sources and selection}

\subsubsection{Policies}

We identified key policies by consulting existing studies on EU energy and climate policy (Boasson and Wettestad, 2013; Görlach et al., 2017; IEA, 2014; Skjærseth et al., 2016). Subsequently, we gathered detailed information about the policies from EU websites. The main source for assessing policies were the original law texts. We also consulted impact analyses for some of the policies, as well as existing studies on policy interaction (Del Río, 2014; IPCC, 2014; Jarke and Perino, 2017). Seven interviews with EU policy makers and stakeholders, as well as informal talks with sector experts provided additional information for the assessment of policies. The list of interviews and interview guide is included in Annex, Table A5+A6. Finally, also newspaper articles, reports and websites with relevant facts and statistics were used.

To select the policies for our analysis, we started with a broad set of policies, which potentially influence different parts of the electricity system including generation, transmission and distribution, and system operation. From these, we excluded

needs the support by the European Parliament. The final renewable energy target will not be clear until the EU adopts a revised Renewable Energy Directive. 
$R \& D$ policies as well as specific support policies for technologies, which are not yet applied in practice. Also policies that address heating or cooling or energy efficiency were excluded, unless there are overlaps with electricity supply and operation (as in the case of cogeneration, smart-metering or storage).

\subsubsection{Actors}

To identify actor preferences, we relied on consultation documents that were submitted by the actors to two public consultation processes, which were recent and central for the ongoing policy processes in relation to the Clean Energy Package. The first consultation is from 2015 on the 'new Energy Market Design' $(\mathrm{NEM})^{9}$, the second is from $2015 / 2016$ on the revision of the 'Renewable Energy Directive for the period after 2020' (RED) ${ }^{10}$. Both consultations have a number of predefined questions to which the actors could respond.

For our study we decided to concentrate on firms, industry associations and environmental NGOs. ${ }^{11}$ These actors play a crucial role in influencing policy and politics. To keep complexity at bay, we deliberately excluded EU member states from the analysis as well as political parties in the European Parliament or the EU Council. Even though we only cover a subset of the relevant constituencies, we believe that analyzing industry actors and NGOs already delivers a comprehensive picture about the main conflict lines.

To identify the most influential actors, we followed a three-step approach. First, we prepared a list of around 70 large, prominent and internationally active organizations. We applied the reputational approach (French, 1969) to assess the actor's influence. In a test-round, we asked three experts on European energy policy to provide feedback on the list. In a second round, the 70 actors were ranked by seven experts. ${ }^{12}$ The experts were asked by email to rank the actors on a scale from 1 to 4, from 'very influential' (1) to 'not influential' (4) with respect to electricity policy. We also asked them to add and rank actors that they thought were missing. In a third step, we compiled the expert feedback. The primary condition to include an actor in our final sample was that it was ranked 1 or 2 by at least two of the experts. This resulted in a list of 42 actors. Another condition was data availability: We only included actors that had submitted at least one response of sufficient length and quality to one of the consultations. Five actors dropped out. As a result,

9 https://ec.europa.eu/energy/en/consultations/public-consultation-new-energymarket-design (10.04.2017)

10 https://ec.europa.eu/energy/en/consultations/preparation-new-renewable-energydirective-period-after-2020 (10.04.2017)

11 To keep it brief, we refer to all of them as industry actors in the following.

12 Two experts work in energy companies, four are researchers on energy and climate issues, and one is an independent energy policy consultant. 
we arrived at a final sample of 37 actors (Table 1). More than half of them are associations, which underlines the high relevance of associations for policy making at the EU level.

Table 1: List of key industry actors in our study ${ }^{13}$

\begin{tabular}{ll}
\hline Energy associations & $\begin{array}{l}\text { CEDEC, Eurelectric, Euracoal, Euroheat \& Power, EASE, Foratom, } \\
\text { SEDC (7) }\end{array}$ \\
\hline Utilities & Dong, EDF, Enel, Eon, Iberdrola, RWE, Statkraft, Total (8) \\
\hline $\begin{array}{l}\text { System operators \& } \\
\text { associations }\end{array}$ & EDSO, Entso-E, ERDF, Tennet (4) \\
\hline Industry associations & BusinessEurope, CEFIC, Eurochambers, IFIEC (4) \\
\hline $\begin{array}{l}\text { Renewables } \\
\text { associations }\end{array}$ & BEE, EREF, EWEA, SolarPowerEurope (4) \\
\hline Technology providers & GE, Alstom (2) \\
\hline Environmental NGOs & CAN, E3G, Greenpeace, WWF (4) \\
\hline Others & Europex, EFET, IEA, ACER (3) \\
\hline
\end{tabular}

\subsection{Specification of the pathway dimensions for electricity}

For our empirical analysis, the two generic pathway dimensions (cf. section 0) need to be operationalized in order to reflect the specifics of the electricity sector. To assess the degree of sustainability for the electricity sector, we focus on renewable energies, which is one of the key elements of sustainable power supply. More precisely, we will analyze the ambitions for the use of renewable energy sources (RES). We acknowledge that there are different ways of operationalizing the sustainability dimension. Some studies focus on decarbonisation (e.g. Verbong and Geels, 2010). This implies that other non-renewable, low-carbon technologies like nuclear and CCS would promote sustainability. However, we focus on renewable energy ambitions because it is a formal target of EU energy policy making, a central topic in several policies and it is explicitly addressed in the consultations we use as data sources to identify actor preferences (see 4.1.2).

To assess disruption, we focus on the degree of decentralization of the electricity system. We analyse policies and actor preferences with respect to whether they support decentralized technologies in electricity production, grids, and system operations (DEC). Given that the electricity system was organized in a centralized way in the past, decentralization represents a major disruption to the power system (Funcke and Bauknecht, 2016; Lilliestam and Hanger, 2016; Schmid et

13 Bold entries ranked 'very influential' by at least one expert. The full names of the actors are listed in Table A4 (Annex). 
al., 2016) ${ }^{14}$. Decentralization of the electricity system not only implies new ways of coordinating and balancing supply and demand but is often also associated with new forms of ownership e.g. by individuals or energy cooperatives (Funcke and Bauknecht, 2016; Scheer, 2006) For incumbent firms, decentralization is also disruptive inter alia because it entails a shift from a mass-market logic with low margins as compared to large investments following a business-logic of large-scale projects (Magnusson et al., 2005).

The issue of (de-)centralization is a major fault line in how actors envision the future electricity system. Actors in favor of a centralized pathway propagate, large wind power parks integrated in an "offshore supergrid" in the North Sea (Airtricity, 2006; Andersen, 2014) for example. Other actors call for a decentralised power system based on small-scale renewables, local microgrids and large numbers of 'prosumers' that both generate and consume electricity (Scheer, 2006). Even though these two visions could be complementary to some extent, they constitute major conflict lines for business models, energy finance or grid operation.

With this specification, we can distinguish four development options for the electricity sector (Figure 3). "Business-as-usual" implies little or no further deployment of renewables. "Centralized RES" represents a major change along the sustainability dimension without much of a disruption for incumbent actors. Such a configuration would be based on large-scale renewables such as offshore wind, and an expansion of transmission grids to balance variable supply and demand.

"Decentralized-RES" points to small-scale distributed renewables, e.g. with PV on every building and consumers turning into prosumers. Such a configuration changes the basic architecture of the electricity sector, including technologies and business models. New services (e.g. direct trading, pooling, demand response, storage, local balancing) will be needed and they may disrupt incumbents and trigger the entry of new actors. "Decentralized self-generation" is similarly disruptive but less sustainable. This pathway could be dominated by small-scale and locally controlled co-generation plants.

Note that the operationalization of the generic dimensions to capture important conflict lines is thus guided both by ongoing developments in the electricity sector (i.e. decentralization) and, to lesser extent, by our concrete data material (i.e. renewables versus decarbonization). This illustrates that the dimensions can be operationalized in different ways across study cases.

\footnotetext{
${ }^{14}$ It is important to note here that there are several European countries that already have a hybrid system due to large degrees of decentralized cogeneration in their electricity systems, e.g. Slovakia (78\%), Latvia (45\%) and Denmark (40\%), numbers are from 2015. (http://ec.europa.eu/eurostat/web/energy/data, downloaded 27.06.2018)
} 


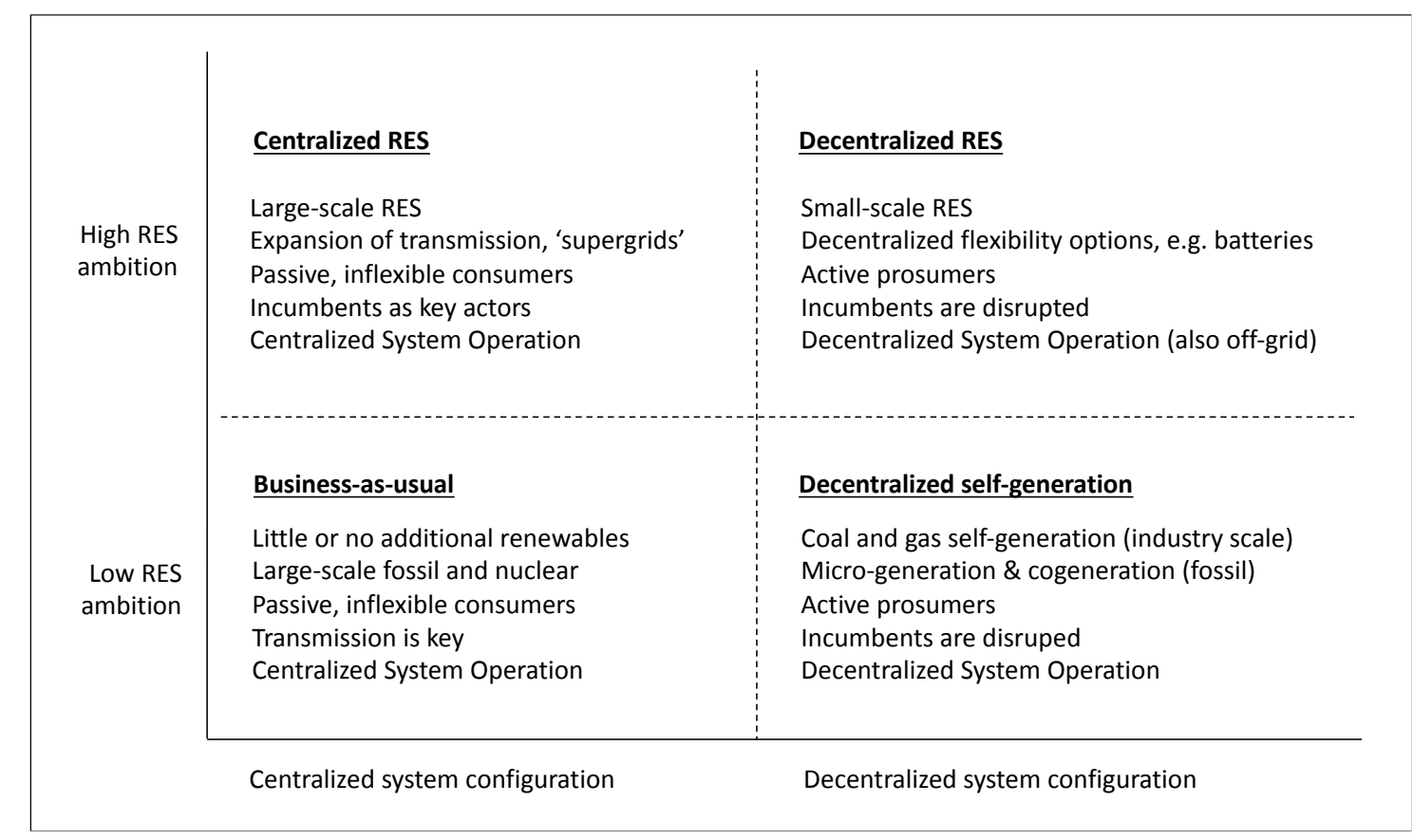

\section{Figure 3: Pathway types}

\subsection{Coding scheme}

A central element of our approach is the coding scheme that specifies how the two main dimensions (RES and DEC) are operationalized to assess policies and actor preferences. Inherent are assumptions about how specific technologies and policy measures will affect (de)centralization and renewable energy deployment.

\section{Table 2: Coding scheme}

\begin{tabular}{|c|c|c|c|}
\hline Dimensions & Sub-dimensions & Policies & Actors \\
\hline \multirow{11}{*}{ 1) (De)Centralized } & 1.1 Decentralized generation & $\mathrm{x}$ & $\mathrm{x}$ \\
\hline & 1.2 Grid fees & $\mathrm{X}$ & $\mathrm{X}$ \\
\hline & $\begin{array}{l}\text { 1.3 Market integration of RES: Balancing responsibilities and } \\
\text { priority dispatch }\end{array}$ & $\mathrm{X}$ & $\mathrm{x}$ \\
\hline & 1.4 Prosumerism & - & $\mathrm{x}$ \\
\hline & 1.5 Demand Side Management & $\mathrm{X}$ & $\mathrm{X}$ \\
\hline & 1.6 Storage & $\mathrm{X}$ & $\mathrm{X}$ \\
\hline & 1.7 Interconnectors & $\mathrm{X}$ & $\mathrm{x}$ \\
\hline & 1.8 Capacity Markets & - & $\mathrm{X}$ \\
\hline & 1.9 System Operation & $\mathrm{X}$ & - \\
\hline & 1.10 ETS should be main policy & $\mathrm{X}$ & $\mathrm{X}$ \\
\hline & 1.11 Competitive bidding RES support & $\mathrm{X}$ & - \\
\hline \multirow{8}{*}{$\begin{array}{l}\text { 2) Renewable } \\
\text { Energy }\end{array}$} & 2.1 RES deployment & $\mathrm{X}$ & $\mathrm{X}$ \\
\hline & 2.2 RES potential & - & $\mathrm{x}$ \\
\hline & 2.3 RES targets & $\mathrm{X}$ & $\mathrm{X}$ \\
\hline & 2.4 RES leads to increased system costs & - & $\mathrm{X}$ \\
\hline & 2.5 RES support & $\mathrm{X}$ & $\mathrm{X}$ \\
\hline & 2.6 MSs must develop grids for RES & $\mathrm{x}$ & - \\
\hline & 2.7 Integrate RES into the power system & $\mathrm{X}$ & - \\
\hline & 2.8 Support fossil / nuclear technology \& infrastructure & $\mathrm{X}$ & - \\
\hline
\end{tabular}


The sub-dimensions were developed in an iterative process switching between deduction and induction, i.e. our ex ante assumptions about the dimensions derived from literature, media and expert discussions as well as subsequent findings in the data. The sub-categories for policy and actor analysis vary slightly, see Table 22. The main reason for this is that the policies have slightly different foci than the issues actors talk about in their responses. For example, very few actors express views on system operation.

To further specify the coding scheme, we developed lead exemplary statements for the coding of submissions into sub-categories. Next, two of the researchers tested the initial scheme independently with a selection of four consultation responses. Subsequently, we revised our initial category system in order to improve precision, reduce the possibility of different interpretations and to adapt to the available data. After several rounds of testing and improvement, the scheme was finalized. In parallel with the analysis of actors, we tested the scheme to analyze the policy mix in a similar way and along the same dimensions. Two examples are given in Table A1 (in Annex).

\subsubsection{Coding of policies and actor preferences}

Each sub-category was coded on a scale from 1-4. An overview on how the scaling works is provided in Table 44. Coding of actors statements was done in Nvivo and coding of policies was done manually and compiled in Excel. In total, three researchers were involved in the coding. The main author did the coding of the policy documents and a second researcher controlled the results. Coding of actor preferences was carried out by two researchers including the main author, each coding half of the submissions. Subsequently both reviewed what the other had coded.

Sub-category rankings were designed in a way that the values point into the same direction and do not offset each other. For example, a preference for increased RES deployment pulls in the same direction as a preference for RES targets. Some actors (and policies) will activate preferences for both centralization and decentralization in different sub-categories. The most prominent example of this are actors expressing strong support for decentralized generation but also highlighting the need for more interconnectors. In such cases, actors and policies will have rankings on opposite sides of the scale, which are eventually aggregated.

For the actor preferences, we systematically coded all relevant statements, even though an actor would repeat herself. If different statements activated different coding values within the same sub-category, the statements repeated more often will be weighted higher. For the policy analysis, we followed a slightly different logic. Here, we did not capture the "perspective of someone", but the value of a specific decision or mechanism, as expressed in the law-text. We therefore only 
counted every policy element once. In order to capture that some decisions are more fundamental and overarching than other, we gave more weight to central policy elements than to minor aspects (see Table 3).

We arrived at the final RES/DEC values for each actor by building averages of the codings for i) each sub-category, ii) across all sub-categories and iii) for both consultations. We chose not to weight between sub-categories, even if one subcategory received much more quotes than another.

\subsection{Policy analysis}

Our analysis considers the EU policies adopted between 2009-2015. We mainly analyzed secondary EU law, i.e. directives and regulations ${ }^{15}$. Some European Council Conclusions are included as well. These are not legally binding, but most targets are subsequently translated into legislation. We included them when these contain relevant policy strategies that are not yet implemented into EU law ${ }^{16}$, e.g the 2030 targets. Due to their direct relevance for electricity generation, we also included the State Aid Guidelines adopted in 2014.

One policy is regarded as one specific directive, regulation or council conclusion and can contain several instruments and strategies. We coded all relevant strategies and instruments within each policy. Strategies and instruments were weighted according to their relevance and potential impact.

We operationalize the term 'policy strategy' to comprise all relevant policy plans and targets stated in the policy documents. They express the normative agenda behind the instruments. This approach deviates slightly from Rogge and Reichardt's (2016) distinction of the notions 'strategy' and 'instrument', since they classify national Acts as instruments and international protocols or EU directives as strategies per se (Rogge and Reichardt, 2016, p. 1628). In our approach, each policy (i.e. the legal text) contains several strategic objectives and various instruments.

We weight policy strategies and instruments according to their scope, policy type and potential impact. Table 3 gives examples of the principles that we applied in the weighting of policies. An example of potential impact assessment is provided in Table A2 (in Annex).

http://eur-lex.europa.eu/legal-content/EN/TXT/HTML/?uri=LEGISSUM:114534\&from=EN (10.04.2017)

16 This is why the 2020 Energy and Climate Package is not included in our mix as one separate policy. All targets and instruments relevant for our dimensions are included in the policy mix analysis through the assessment of directives and regulations. 
Table 3: Weighting of policies

\begin{tabular}{|l|l|}
\hline Weight & Principles for the weighting of the policy elements: \\
\hline 2 & $\begin{array}{l}\text { Instruments and strategies with outstanding importance. Outstanding importance } \\
\text { implies: a) scope: the instrument applies for a large technological/policy field, or for a } \\
\text { large number of the involved actors, or b) importance: it represents the main } \\
\text { instrument/mechanism of the policy. Example: binding RES targets for all EU MSs in } \\
\text { the Renewable Energy Directive. }\end{array}$ \\
\hline 1 & $\begin{array}{l}\text { Instruments and strategies that state general targets and prescribe different } \\
\text { instruments. Example: The Renewable Energy Directive allows support schemes for } \\
\text { renewable energy, but does not make them mandatory (2009/28/EC, Article 3, 1. a),b)) }\end{array}$ \\
\hline 0.5 & $\begin{array}{l}\text { Instruments that represent minor exemptions from the overall instrument, or apply only } \\
\text { for a small number of actors. Strategies that state general policy preferences, but not } \\
\text { necessarily targets. Example: Statement that stresses importance of smart-grids in the } \\
\text { PCI-regulation from } 2013 \text { (No 347/2013, Preamble Number (8)) }\end{array}$ \\
\hline
\end{tabular}

As an overall guideline, instruments are considered more important than strategies, since they are the actual governing mechanisms or "techniques of governance" that "give effect to public policy" (Howlett and Rayner, 2007, p. 2). However, long-term strategies are also important since they send out strong signals on future credibility of the policy mix (Reichardt and Rogge, 2016).

We perform a qualitative assessment of current legislation's potential impact on our two dimensions by ranking them on a scale from 1-4. For details on the ranking, see Table 4.

Table 4: Dimensions and scales for coding

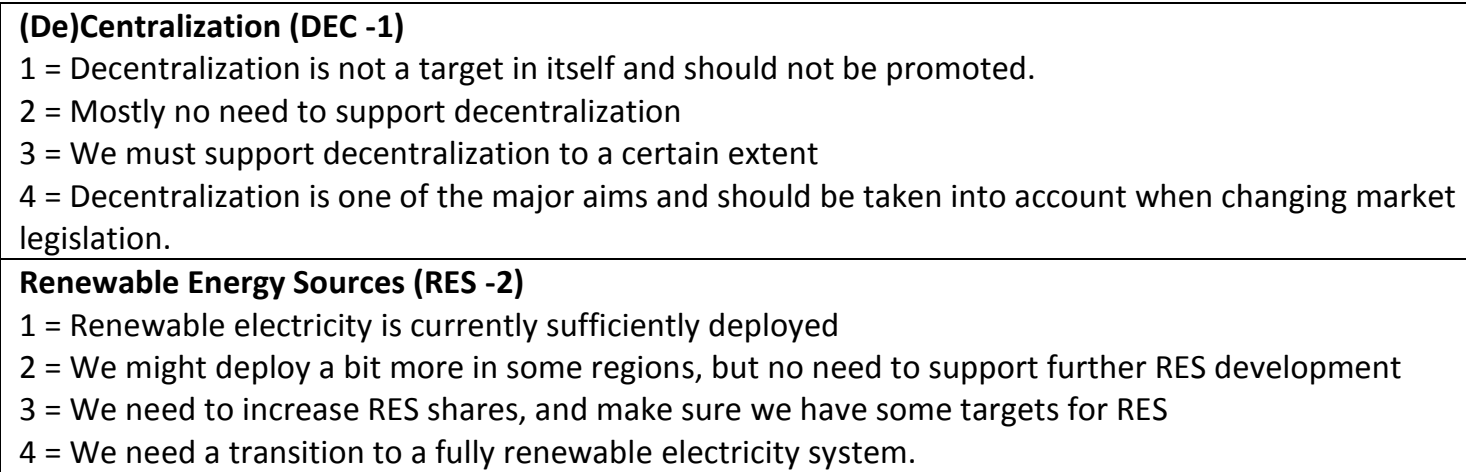

When assessing potential impact of EU policies, we must take into account that the impact of EU legislation heavily depends how they are converted into domestic legislation (Skjærseth et al., 2016). This is, however, beyond the scope of this paper.

To arrive at the policy ranking, we calculated the weighted average for all strategies and instruments for each dimension. An example of policy coding and calculation is included in Table A3 (in Annex). For the final mapping of each policy, we obtain one value for the renewable dimension (hereafter: RES) and one for the (de)centralized dimension (hereafter: DEC). 
Note that our temporal delimitation of policies, 2009-2015, implies that the consultations providing our data on actors do not cover the policy process the analyzed policy mix. The policy preferences are hence partly a reaction to the implemented policy mix, and cannot be used as an explanation for the policy outcome. Moreover, the policy preferences reflect key actors' positions in the process of creating a future policy mix.

\subsubsection{Interaction}

The policy mix literature have proposed different criteria for assessing interaction between the elements of the mix, including consistency, coherence, congruence and credibility (Rogge and Reichardt, 2016). Consistency is defined as a two-fold relation: a) the relation between instruments and objectives, and b) the relation between instruments. For the former, consistency is defined as whether the instruments are able to ensure that specific targets are achieved. For the latter, consistency describes whether instruments enhance or modify each other's effect with respect to given objectives when co-existing in a mix. Inconsistency is characterized by strong or weak conflicts, i.e. when one instrument reduces the effect of another or, when the impact of the combination is lower than if both instruments are used separately (Del Río, 2014).

An important distinction is hence between different types of policy mix analyses according to whether the policy mix has just one or several targets, since it should assess the instruments with respect to objectives. Most often, policy instruments operating within the same policy field will have different objectives and serve several purposes. Policy analysts should therefore consider whether they take all objectives in the mix into consideration, or only select one or a few.

Since the objectives of the EU's energy policy are diverse, manifold and multileveled, assessing interaction of instruments with respect to multiple objectives would be a task of great complexity. Given that most of the policies do not have outspoken (de)centralization objectives, we propose an alternative approach in which consistency is defined as the policies' interaction effect with respect to our two pathway dimensions. Our assessment of the policy interactions is derived from a literature review of the main interactions in the policy mix, and from interview data. 


\section{Results}

\subsection{Policy mix analysis}

\subsubsection{EU electricity policies}

The policy mix contains 11 policies: five directives, three regulations, two council conclusions and one communication with guidelines from the Commission (Table 5). The most important policies are the Electricity Market Directive, the Electricity Regulation and the Renewable Energy Directive. The first two are at the core of the Third Energy Package targeting market liberalization, unbundling of generation and grid operation, increased cross-border trade and establishing institutions to implement and control these developments. The TEN-E and DATA regulations are also part of the Third Energy Package. The former establishes the list of Projects of Common Interests and lays down rules for the "timely development and interoperability of trans-European energy networks" (preamble 17). The latter regulates the responsibility for data management with transmission system operators.

The ETS directive is about a cap-and-trade system for greenhouse gas emissions, while the Renewable Energy Directive formulates targets for renewables, which are to be supported at national levels. The Energy Efficiency Directive and the Energy Performance for Buildings Directive primarily address energy efficiency measures, with some implications for electricity generation. Council Conclusions formulate additional policy strategies, above all the 2030 energy and climate targets. These targets will be implemented into law in the 'Clean Energy Package' (see chapter 3). Finally, the State Aid Guidelines make provisions for the design and type of renewables' support the Member States are entitled to grant.

Table 5: List of key EU electricity policies

\begin{tabular}{|c|c|c|}
\hline Year & Policies & Label \\
\hline 2009 & $\begin{array}{l}\text { Directive } 2009 / 28 / \mathrm{EC} \text { on the promotion of the use of energy from } \\
\text { renewable sources }\end{array}$ & RED 2009 \\
\hline 2009 & $\begin{array}{l}\text { Directive } 2009 / 29 / \mathrm{EC} \text { on the greenhouse gas emission allowance } \\
\text { trading scheme of the Community }\end{array}$ & ETS 2009 \\
\hline 2009 & $\begin{array}{l}\text { Directive } 2009 / 72 / \mathrm{EC} \text { concerning common rules for the internal } \\
\text { market in electricity }\end{array}$ & EMD 2009 \\
\hline 2009 & $\begin{array}{l}\text { Regulation (EC) No } 714 / 2009 \text { on conditions for access to the } \\
\text { network for cross-border exchanges in electricity }\end{array}$ & ElReg 2009 \\
\hline 2010 & Directive $2010 / 31 / \mathrm{EU}$ on the energy performance of buildings & EPBD 2010 \\
\hline 2012 & Directive 2012/27/EU on energy efficiency & EED 2012 \\
\hline 2013 & $\begin{array}{l}\text { Regulation (EU) No } 347 / 2013 \text { on guidelines for trans-European } \\
\text { energy infrastructure. }\end{array}$ & TEN-E 2013 \\
\hline
\end{tabular}




\begin{tabular}{|l|l|l|}
\hline 2013 & $\begin{array}{l}\text { Regulation (EU) No 543/2013 on submission and publication of data } \\
\text { in electricity markets }\end{array}$ & DATA 2013 \\
\hline 2013 & $\begin{array}{l}\text { European Council Conclusions ( 23 May 2013) } \\
2014\end{array}$ & $\begin{array}{l}\text { Council } \\
\text { Conclusions } \\
\mathbf{2 0 1 3}\end{array}$ \\
\hline 2014 & $\begin{array}{l}\text { Guidelines on state aid for environmental protection and energy } \\
\text { 2014-2020. (2014/C 200/01) }\end{array}$ & $\begin{array}{l}\text { Council } \\
\text { SA 2014 }\end{array}$ \\
\hline
\end{tabular}

\subsubsection{Policy mix characteristics}

Figure 4 shows how the different policies compared in terms of their ambition to support renewables (RES) and their potential for disruption in terms of decentralization (DEC). The importance of the policies is reflected in the size of the dots. Our assessment shows quite some variation between policies on both dimensions. We observe much greater variation for decentralization than for RES support. For seven policies, RES-values lie between 2.5 and 3. Two policies are around 3.5 and another two below 2. On the DEC scale, eight policies are in the left part of the scale, many of them with values around 1.5 and lower. Three policies (RED, EPBD, EED) achieve high values around. The Electricity Market Directive is a rather neutral policy on the DEC scale.

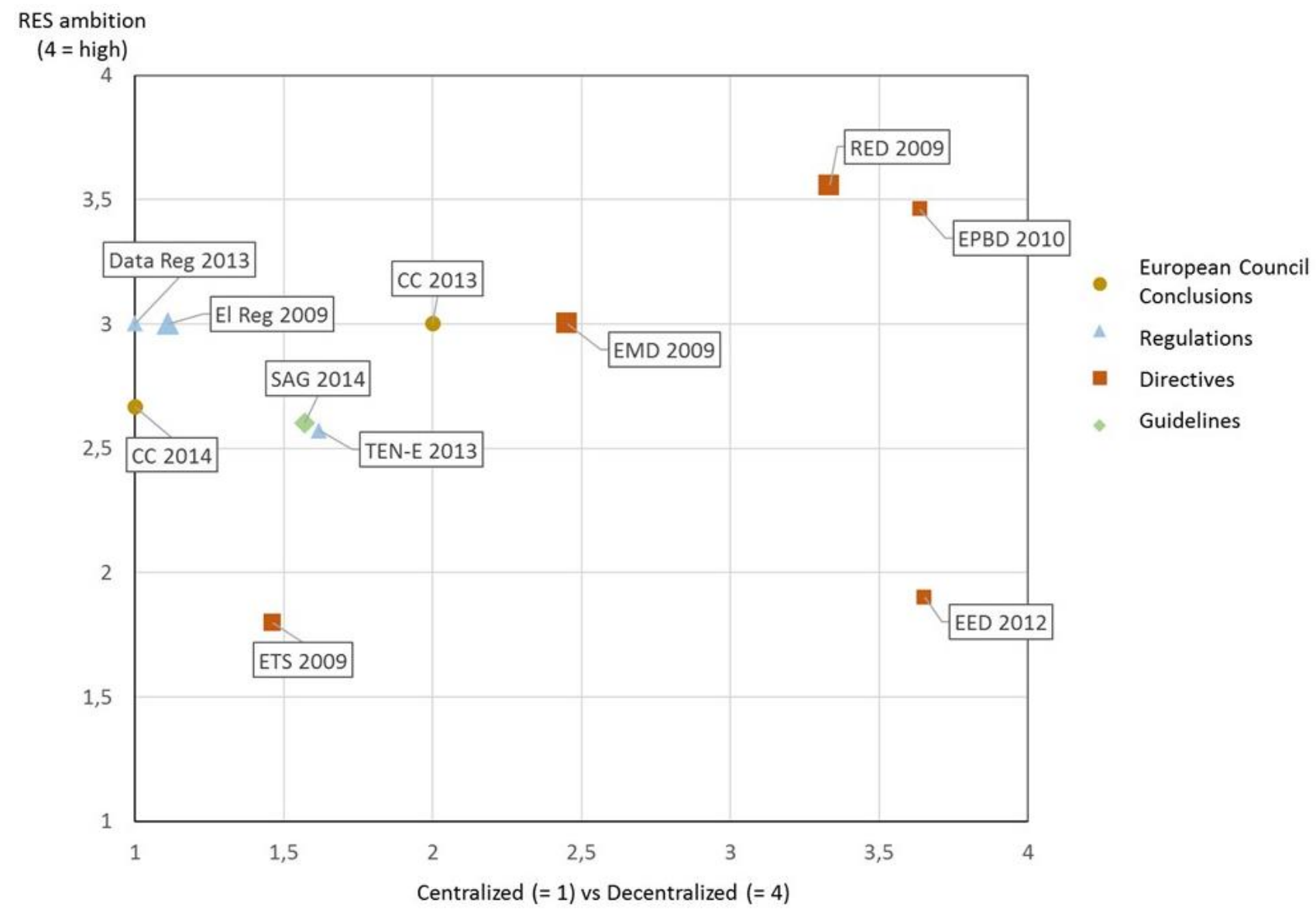




\section{Figure 4: Assessment of EU electricity policies}

The variation on the DEC scale can be further explored by explicitly considering the three main areas of the electricity system: generation, grids and system operation. These dimensions exhibit different degrees of decentralization.

First, there are decentralizing elements in the form of support for specific types of electricity generation. The policies promoting decentral electricity generation are policies whose primary objective is to enhance renewable energy (RED), on-site local energy production (EPBD) and combined heat and power (EED). At the same time, other policies (SAG, CC, and ElReg) emphasize the importance of competition ('level playing field') among all technologies and of not 'disturbing' the market regardless technology maturity which tends to favor big investors and large-scale projects. The generation side seen in isolation thus provides a mixed picture on the DEC scale.

Second, as to electricity grid deployment, we observe a strong focus on transmission grid (interconnectors) construction. The policy elements for smart grids and demand response are fewer and weaker. This corresponds to a centralized bias within the EU's electricity grids policy. One interviewee confirms this finding:

“...it [the PCI-list] is only related to transmission systems, and it's a shame because it could be used also for developing more smart grids and, I think, a tool for developing a more decentralized approach for the electricity system. ... smart grids and distribution grids are completely taken out of that. It's a pity." (I7)

Third, when it comes to system operation, the main responsibility lies with the transmission system operators (TSOs). Traditionally, the TSOs have been responsible for managing the entire electricity system, and the third energy package strengthens the status of the TSOs, which is why we find that system operation is predominantly centralized.

"Its a very centralized system. The operation of the system is very centralized (...) The planning of the system tends to be very centralized. At the end of the day, the responsibility for stability and keeping the lights on is with the TSOs." (I4)

Summarizing the results on the DEC-scale we find that the main policies in the Climate and Energy Package have elements of decentralization, whereas the policies in the Third Energy Package are very or rather centralized. A main exception is the Electricity Market Directive, which has a neutral value on the DEC scale. The main reason for this is that it is a very comprehensive directive with a large number of Articles on different issues, which encompasses both decentralizing and centralizing elements.

Smaller variation on the RES scale reflects the fact that between 2009 and 2015 legislation had to take the EU's renewable energy target of $20 \%$ into account. In 
our assessment, all the policies in the Third Energy Package support an 'Centralized-RES' transitions pathway. This is a result of a moderately high RES ambition combined with centralizing policy elements.

The main outliers on the RES scale are the ETS and the Renewable Energy Directive. The low ranking of the ETS (1.8) reflects its main principle of reducing emissions where this is most cost-efficient, thereby favoring production improvements instead of creating incentives to invest in renewable energy. ${ }^{17}$ As a result, we assess the ETS to be the only policy compatible with a 'business-asusual' pathway. The Renewable Energy Directive is the most important and most ambitious policy with respect to renewable energy. It also highlights the role of decentralization of and citizen participation in renewable energy deployment:

"In order to stimulate the contribution by individual citizens to the objectives set out in this Directive, the relevant authorities should consider the possibility of replacing authorizations by simple notifications to the competent body when installing small decentralized devices for producing energy from renewable sources." (Preamble 43, p.21).

The Energy Performance for Buildings Directive creates incentives for on-site renewable energy production in buildings and therefore also scores high on the DEC scale. This is confirmed by several interviewees (I1, I2, I4, I7). Strong decentralization combined with high renewable ambitions implies that these policies support the 'Decentralized-RES' pathway.

Finally, the energy efficiency directive's low RES and high DEC values are due to its promotion of decentralized cogeneration, irrespective of whether this generation is fueled with renewable or fossil energy. As a result, this is the only policy which is compatible with the 'Decentralized self-generation' transitions pathway.

\subsubsection{Policy interactions}

This section addresses the interaction of policies and its implications for our two main dimensions. The focus is on consistency, cf. section 4.4.1. On the DEC scale we find considerable negative consistency arising from differences between a very centralized Third Energy Package and the strong decentralized elements in the Climate and Energy Package.

One part of the negative consistency is a tension between traditional, centralized system operation and support for decentral production. This tension seems to be growing because centralized system operation is increasingly incompatible with the large amounts of decentralized production that has entered the system:

17 Prices fell from $€ 29$ to below $€ 4$ from July 2008 to June 2013 , rose slightly thereafter before they dropped to below $€ 4$ again in September 2016. https://sandbag.org.uk/2016/09/02/eu-carbon-price-falls-below-e4-2/ (31.10.2017) 
"Policy officer 1: If we should plan the power system today from scratch, we would probably build it very differently.

Policy officer 2: That's the key point - the whole system is built for stable generation.

Policy officer 1: We would probably start with the distribution system." (I3)

At the heart of this tension, is the need for adding more 'flexibility' to the power system to integrate increasing shares of variable renewable energy. Flexibility can be added either through centralized (e.g. interconnectors, centralized pump storage and flexible thermal power plants) or decentralized options (e.g. aggregators, smart grids and decentral storage). In the extant policy mix, the former strategy is by far the most dominant. In order to overcome this imbalance, the Commission inter alia attempts to involve local grid companies (DSOs) in system operation to a much larger extent and enhance the cooperation between DSOs and TSOs (I3).

However, centralized grid deployment does not necessarily stand in contrast to decentralization of electricity production. Many actors (I1, I7), for example, perceive interconnectors as an important way to provide more system flexibility and balance intermittent renewable generation:

"You will not manage to integrate renewables if you don't think 'cross-border', this is completely impossible, you need cross-border grids and cross-border trade" (I1)

Still, our analysis suggests that a certain degree of decentralization within system operation and grids is increasingly necessary to cope with growing shares of decentral production.

The policy interaction analysis illustrates that the potentially detrimental effects of the negative consistencies on the DEC scale are mitigated by distinguishing between generation, grids, and system operation. The reason is that centralized and decentralized options and policies can be complementary across these three different segments of the power system at the same time as they can be in competition or inconsistent within each segment. This insight suggests that a more nuanced policy mix analysis explicating the interplay between power system segments would identify hybrid transition pathways which exhibit consistencies that escape our terminology.

In terms of renewables ambitions, most policy pairs apart from the ETS and the Renewable Energy Directive are not characterized by negative consistency in the sense that they modify each other's effect on renewable energy deployment. However, they vary in their ambition level for renewables deployment. One obvious reason is that these policies are not created to facilitate RES, but pursue other objectives like security of supply and competitiveness.

The most salient policy interaction in the policy mix is the influence of renewable energy targets and support schemes in the Renewable Energy Directive on the ETS. 
This policy interaction is extensively treated in the literature (e.g. Böhringer and Rosendahl, 2010; Goulder, 2013; Matthes, 2010) and also highlighted by several interviewees as important (I2, I4, I5). There are two main mechanisms at play. The first is the effect of subsidies for renewables on the price of European Union Allowances (EUAs). The second is the effect of renewable policies on overall GHG emissions when the electricity sector is subject to a cap-and-trade system. As to the first mechanism, theoretical work and simulations achieve highly significant effects of renewable subsidies on the carbon price (Fankhauser et al., 2010; Van den Berg et al., 2013) while other studies find modest impact (Koch et al., 2014, p. 681). The evidence is thus inconclusive. Regarding the second mechanism, scholars have argued that renewable energy promotion "has no effect on total carbon emissions at all if the electricity industry is also subject to a cap-and-trade system" (Jarke and Perino, 2017, p. 103). The strategy for renewables deployment set out in the ETS is hence inconsistent with a renewable energy target as such ${ }^{18}$.

Considering the Renewable Energy Directive's objective to increase renewable energy shares, the ETS would not be able to deliver on this without being reformed. Even prices six times above the 2016 price $(\sim 5 € /$ ton) would not provide sufficient incentive for renewable energy deployment. ${ }^{19}$ Hence, the ETS (as of 2015) as the main climate policy appears inconsistent with specific targets for renewables. In this case, inconsistency in the policy mix clearly mitigates the effect of each policy.

\subsubsection{Summary}

Our policy analysis shows that many EU energy policies are moderately ambitious with respect to our RES dimension, which is in line with the long-term targets of the EU and supportive of a sustainability transition.

As to our DEC scale, the picture is more heterogeneous. There are policies that clearly support a centralized transition pathway while others are in favor of decentralized options. This picture reflects that the extant policy mix was designed to regulate a very centralized power system. However, with increasing focus on environmental and climate issues, some strongly decentralizing elements were introduced into the policy mix. As a result, most policies fall in the "CentralizedRES pathway" quadrant. The results are nuanced by distinguishing between generation, grids, and system operation with the latter two strongly centralized while policies do contain some support for decentralized generation.

18 The directive states that the "main long-term incentive for [...] new renewable energy technologies is that allowances will not need to be surrendered for $\mathrm{CO} 2$ emissions which are [...] avoided" (ETS directive (2009/29/EC), number 20.

19 https://carbon-pulse.com/category/eu-ets (10.04.2017) 
An important issue for the future will be whether system operation and grids deployment will become more decentral to integrate larger shares of decentralized generation.

\subsection{Analysis of actor preferences}

\subsubsection{Industrial actors and their policy preferences}

Our findings show that key actors hold a broad variety of policy preferences (Figure 5). With regard to renewables, a majority of actors are in favor of further renewables deployment. Of these, eight actors including NGOs and renewable energy associations stand out with very high ambitions, highlighting the need for binding targets to achieve climate targets and that the role of the EU:

"As a wealthy and technologically advanced region, the EU could and should aim to achieve a share of $100 \%$ renewable energy before 2050 , by exceeding these 2030 milestone goals." (WWF, NEM consultation, 2015, p. 2)

"The lack of binding national renewables targets post-2020 is a barrier as these targets are the only realistic way to ensure member states level the playing field and enable renewables to compete." (CAN, RED consultation, 2015, p. 9)

At the low end of the RES scale, actors express low or rather low renewable ambitions. Six of these actors are ranked 'very influential', including BusinessEurope, CEFIC or IFIEC:

"Cefic does not support binding renewable energy (RE) targets to 2030" (CEFIC, RED consultation, 2016, p. 7)

"Technologies that cost 200-300 percent more than a product price should not be rolled out at the level of the RES target." (IFIEC, RED consultation, 2016, p. 8) 


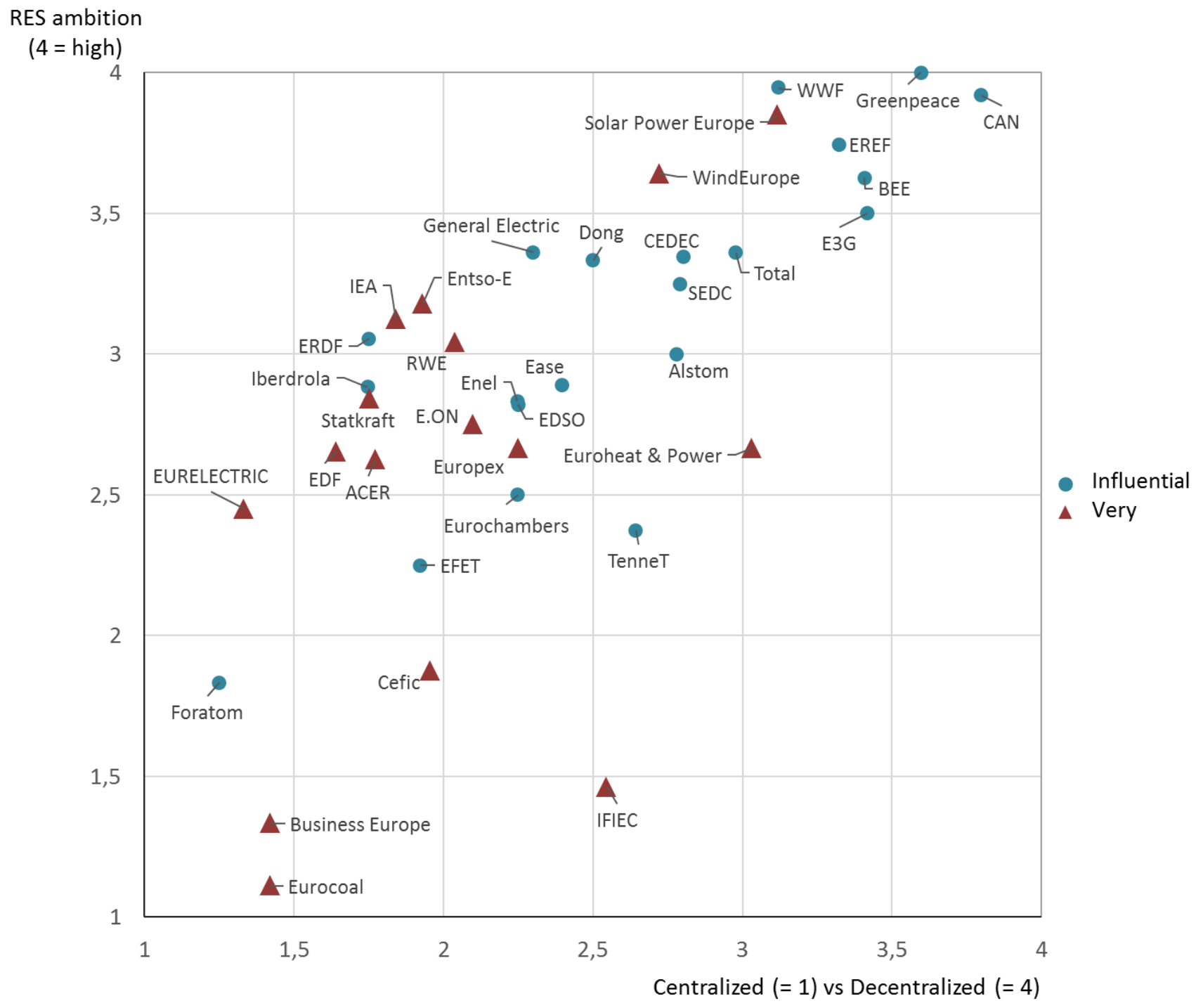

Figure 5: Key actors and their policy preferences

With regard to decentralization, a majority of actors favor a rather centralized configuration of the electricity system. Among these actors are 11 ranked 'very influential'. These actors want to remove and avoid privileges for distributed generation.

"Energy policy should ensure cost effective deployment of RES potential in general, without different treatment of certain types of potential (small, distributed, specific technologies)." (Statkraft, RED consultation, 2016, p. 18)

"Opting for distributed generation should be a customer choice that does not result from artificial incentives. ... Distributed generation should be integrated to the market and the so-called 'consumer divide' must be avoided" (Eurelectric, RED consultation, 2016, p. 19 and p. 2)

In contrast to that, NGOs and renewable associations strongly prefer decentralized configurations and highlight the important role of prosumers. Overall, just a few actors clearly favor a more decentralized electricity system. They suggest that local generation has a higher value due to less need for costly transmission and claim 
the right of citizens to generate their own electricity. Interestingly, IFIEC as a large industry association also makes this point as several of their members also selfgenerate electricity.

"For the EU to scale up and lead renewable energy production, many more renewable energy projects must be created in every community in every member state. The revised RED must therefore support and track local and community-based energy and secure the citizens' right to produce, store and consume their own renewable energy." (Greenpeace, RED consultation, 2016, p. 18)

"An EU-wide right to self-generate, self-consume and store energy is a prerequisite in order to develop renewable energy at the local level. ... local production has an increased value (from a system perspective) if it is consumed locally and not transported over long distances." (WWF, RED consultation, 2016, p. 28)

In terms of different transition pathways, we see that the business-as-usual quadrant is occupied by actors that want to maintain a centralized electricity system based on fossil and nuclear generation. All actors with this preference are associations and many of them are considered 'very influential'.

The upper left corresponds with the Centralized-RES pathway. These actors are in favor of expanding renewables while maintaining centralized system configurations. We find that most utilities and seven very influential actors are in this quadrant.

The upper right represents the Decentralized-RES pathway with high RES and high DEC values. This is where we find all renewable energy associations and NGOs. The latter argue that high renewable ambitions necessarily implies a high degree of decentralization. We find a large number of actors with a high RES and highly decentralized preference, but just three of them are considered 'very influential'. Interestingly, also three large firms (Total, Alstom and, to a lesser extent, Dong) are located here. These are clearly distant from most other companies. Two associations, CEDEC and SEDC highlight the importance of strong local distribution grids and question the need for large-scale deployment of high-voltage transmission lines:

"[Harmonized and EU-wide level support schemes] ignore the possibility to limit contested transmission lines (and the associated costs) by locating generation near consumption sites." (CEDEC, RED consultation, 2016, p. 11)

The lower right quadrant - decentralized self-generation - contains only two actors, IFIEC and Tennet, that have moderate decentralized values. This indicates that they are not actively promoting a decentralized pathway. However, IFIEC highlight the role of prosumers combined with a preference for removal of renewable support. 


\subsubsection{Summary}

Key actor preferences show considerable variation along both dimensions. A majority of actors support further expansion of renewables. Many actors, including many 'very influential' ones, favor a centralized configuration of the electricity system. In contrast, renewable energy associations and especially NGOs, have stronger preferences for decentralization. Many of them regard decentralization in itself as an important goal of the energy transition and argue that a transition can only take place in conjunction with further decentralization. Moreover, we also find differences among the incumbent actors. Some large firms (General Electric, Dong and Total) are more in favor of renewables than others and some (Total, Alstom and TenneT) are more open to decentralization. This suggest that they pursue different strategies associated with different sustainability transition pathways.

\subsection{Comparison of policy and actor analysis}

Our analysis shows that, by and large, there are similar priorities when comparing the policy mix and the preferences of key industry actors. The majority of actors and especially many influential ones - prefer a 'centralized RES' pathway. This is also the pathway that is primarily supported by the current policy mix. At the same time, there are also many actors with strong preferences in favor of decentralization and more ambitious support for renewables. Also these positions find support by some of the policies.

The analysis also shows that there is quite some variation both in the policy mix and in the actor preferences. This points to major conflict lines between different actors and their interests. Our findings suggest that the question of decentralization is more contentious than the issue of renewables, since increasing decentralization can have more disruptive potential and thus poses a greater threat to the business of incumbent actors. The interviews confirmed that the question of decentralization versus centralization is highly conflictive. However, interviewees also agreed that decentralization is taking place, regardless of the underlying struggles of actors.

Given that the power system used to be very centralized, the few policies that favor decentralization already tend to disrupt the current order of things. It seems evident that incumbents try to counter this development. In this context, our analysis suggests that the future 'battle' will be more about the direction (i.e. system configuration) of the energy transition, rather than about obstructing it. 


\section{Discussion and conclusions}

This study has provided a comprehensive assessment of to what extent the EU's electricity policy mix supports different transition pathways as well as the pathway preferences of key industry actors. It has shown that both policies and actor preferences vary considerably in their ambition to support renewable energies and whether to pursue centralized or decentralized system configurations. We find that the current EU energy policy mix strongly favors centralized options with respect to transmission and system operation but supports both centralized and decentralized electricity generation. Most actors favor continued centralization and express moderate ambitions for further renewable energy support. Many of these actors are energy incumbents and their associations. Environmental NGOs and renewable energy associations, in contrast, have high ambitions for renewable energy and strongly favor a decentralized electricity system.

As a consequence, there is a main conflict line between incumbent actors that want to continue along a centralized pathway and those who want expand the support for decentralized renewable power generation. Environmental NGOs and renewable energy advocates ask for increased decentralization in system operation and grid management, in order to facilitate large shares of decentralized, variable generation in the electricity system. Incumbent actors, in contrast, argue that Europe must pursue a cost-efficient transition pathway, in which the ETS is the main instrument and that renewable energies should not be privileged any longer.

These findings are supported by recent analyses of EU climate policy, which found that the 2030 targets adopted in 2014 were in line with the preferences of large traditional utility companies and their associations, and to some extent with energy-intensive industries (Fitch-Roy, 2017; Ydersbond, 2016). Also, a recent study on the lobbying impact of trade associations on EU climate policy found these associations to be very influential and to promote rather defensive positions (Fagan-Watson et al., 2015).

The fact that we find higher variation in actor preferences on the issue of decentralization than on renewables ambition seems to indicate that the electricity sector is currently in a situation characterized by a relatively broad agreement about the need for more renewable energy (i.e. a sustainability transition) but more conflicting views about which power system configuration to pursue (i.e. degree of decentralization).

Another result of our study is that there are differences in the positions of energy incumbents. We observe that some of the incumbents take a more proactive role in the transition in order to maintain their dominant positions in a renewable electricity system. This mixed picture of incumbents' positions suggests that they follow different strategies, and that the EU energy transition is moving to the next 
stage and beyond the usual pattern of all incumbents resisting change. In fact, we might see in the future that some incumbents pursue more radical and disruptive innovation (Andersen and Markard, 2017; Berggren et al., 2015; Markard and Truffer, 2006).

It is important to keep in mind that changes in policies, actor preferences and technologies are all interrelated (Edmondson et al. (this issue); Geels, 2004; Markard et al., 2016). Even though the Centralized-RES pathway currently receives most support from policies and actors, rapid technological developments in solar power, smart grid technology and distributed storage are continuously making a Decentralized-RES pathway more feasible (Lazard, 2017; REN21, 2017). In fact, several interviewees pointed to technology development as a key driver for decentralization (I1, I2, I6, I7).

We expect the EU policy mix and actor preferences to gradually adapt to a new technology landscape. Therefore, the current support for a centralized pathway might not be long-lasting and the energy transition could progress much faster than current policies and preferences suggest. The ongoing negotiations at the EU level about new elements for the policy mix (e.g. the 'clean energy package') can also be seen as a need to align policies to a new technological and industrial reality where decentralized technologies are competitive, reliable, and rapidly expanding (Mitchell, 2016; Schmidt and Sewerin, 2017).

Our study has some limitations. Since we included a large number of policies in our analysis, we were not able to assess their emergence and interaction in great detail. However, our research design enables a larger view on all relevant policies than when concentrating on a few. In the actor analysis, we deliberately excluded EU member states and institutions that are formally involved in policy making, which means our assessment of key actors remains incomplete. We argue that the focus on industry actors nonetheless provides important insights into the main conflict lines and are also helpful for understanding ongoing and future negotiations about EU energy policies. A third limitation is that we did not study how policies or preferences changed over time. This is certainly a promising topic for further research in order to understand how conflicts over the direction sustainability transitions emerge and change over time. It will be particularly interesting to see what happens if actor preferences become more 'fluid' and change at a larger scale.

In conclusion, our study makes three major contributions. First, to the literature on policy mixes, we add an explicit perspective on industry actors and interest organizations. Our analysis has explicitly taken into account the policy preferences of key actors, which form a confined part of the policy process and are hence of major relevance for policy mix studies (Flanagan et al., 2011; Reichardt and Rogge, 2016). We argue that it is important to identify main conflict lines among different 
groups of actors. Such a perspective can support navigation in contested terrains, inform policy makers about the feasibility of new policies, identify supportive and resistant constituencies, and identify possible areas of compromise.

Second, we contribute to the literature on transition pathways (Geels and Schot, 2007; Rosenbloom, 2017) with a focus on the underlying politics. Our two dimensions reflect that there are struggles over societal values (sustainability), as well as struggles over material interests (disruption). Also our approach to sustainability is novel. Previous studies either explored potential socio-technical pathways towards a specified sustainability target (e.g. Verbong and Geels, 2010) or concentrated on other dimensions than sustainability (Geels et al., 2016b; Geels and Schot, 2007). Making the degree of sustainability a central part of the analysis, reveals which actors support, or resist this central goal and for what reasons.

Our final contribution is a methodological one. We propose a novel approach to systematically compare actor preferences and policies in a policy mix by establishing a set of categorical variables, according to which we code policies and preferences on a 1-4 scale in order to quantify the results. This will be helpful for future studies that either track the politics of transition pathways over time, or explore the interplay of institutional, technological and organizational change in a more detailed way. In our case study, we showed that sustainability and disruption are generic dimensions that can be useful for capturing the characteristics of an unfolding transition. Our analysis is one of the first to provide a comprehensive assessment of the alignment of policy mix and industry actor preferences at the EU level.

Transitions in general, and sustainability transitions in particular, are contested and value-laden. Hence, identifying and studying main conflict lines is essential when carving out future policy mixes with respect to sustainability transitions. This is an avenue of future research which becomes all the more important as sustainability transitions advance. When novel technologies mature, this has implications for the configuration of socio-technical systems as well as for the corresponding adaptation of policy mixes. Against this background, our study can be helpful for systematically analyzing potential synergies as well as conflicts between transition policies, actor preferences and politics at international and national levels.

\section{Acknowledgements}

We gratefully acknowledge the funding for this research from the Norwegian Research Council as a part of the project on the "Integration of Power Transmission Grids" (InGrid, Grant number 24 3994/E20). One author has also received funding 
from the Swiss Competence Center for Energy Research (SCCER CREST), financially supported by Innosuisse under Grant No. KTI 1155000154.

We would like to thank two anonymous reviewers and Florian Kern, the handling guest editor, for their valuable comments. A special thanks to the seven interviewees and the members of the expert group who identified influential actors. We also thank Gunn Birgitte Skoge Nygard, who assisted with coding of actors.

Further, we thank the project members of the InGrid project and Inga Margrete Ydersbond, Torbjørg Jevnaker, and Elin Lerum Boasson for helpful comments. The paper also profited from feedback at the IST 2017 Conference and ECPR 2017 General Conference. 


\section{References}

Agora Energiewende, 2017. The cost of renewable energy: A critical assessment of the Impact Assessments underlying the Clean Energy for All EuropeansPackage. Agora Energiewende.

Airtricity, 2006. European offshore supergrid proposal. Dublin.

Alkemade, F., Hekkert, M.P., Negro, S.O., 2011. Transition policy and innovation policy: Friends or foes? Environ. Innov. Soc. Transitions 1, 125-129. https://doi.org/10.1016/j.eist.2011.04.009

Andersen, A.D., 2014. No transition without transmission: HVDC electricity infrastructure as an enabler for renewable energy? Environ. Innov. Soc. Transitions 13, 75-95. https://doi.org/10.1016/j.eist.2014.09.004

Andersen, A.D., Markard, J., 2017. Innovating incumbents and technological complementarities: How recent dynamics in the HVDC industry can inform transition theories., TIK working papers on Innovation Studies. Oslo, Norway.

Bergek, A., Berggren, C., Magnusson, T., Hobday, M., 2013. Technological discontinuities and the challenge for incumbent firms: Destruction, disruption or creative accumulation? Res. Policy 42, 1210-1224. https://doi.org/10.1016/j.respol.2013.02.009

Berggren, C., Magnusson, T., Sushandoyo, D., 2015. Transition pathways revisited: Established firms as multi-level actors in the heavy vehicle industry. Res. Policy 44, 1017-1028. https://doi.org/10.1016/j.respol.2014.11.009

Boasson, E.L., Wettestad, J., 2013. EU Climate Policy: industry, policy interaction and external environment. Ashgate, Surrey, England.

Böhringer, C., Rosendahl, K.E., 2010. Green promotes the dirtiest: On the interaction between black and green quotas in energy markets. J. Regul. Econ. 37, 316-325. https://doi.org/10.1007/s11149-010-9116-1

Dahlin, K.B., Behrens, D.M., 2005. When is an invention really radical?: Defining and measuring technological radicalness. Res. Policy 34, 717-737. https://doi.org/10.1016/j.respol.2005.03.009

Del Río, P., 2014. On evaluating success in complex policy mixes: The case of renewable energy support schemes. Policy Sci. 47, 267-287. https://doi.org/10.1007/s11077-013-9189-7

Dijk, M., Wells, P., Kemp, R., 2016. Will the momentum of the electric car last? Testing an hypothesis on disruptive innovation. Technol. Forecast. Soc. Chang. 105, 77-88.

Dolata, U., 2009. Technological innovations and sectoral change. Transformative capacity, adaptability, patterns of change: An analytical framework. Res. Policy 38, 1066-1076. https://doi.org/10.1016/j.respol.2009.03.006

Edmondson, D.L., Kern, F., Rogge, K.S., (this issue) The co-evolution of policy mixes and socio-technical systems: Towards a conceptual framework of policy mix feedback in sustainability transitions. Res. Policy. https://doi.org/10.1016/j.respol.2018.03.010

European Commission, 2015. Achieving the 10\% electricity interconnection target. https://doi.org/COM(2015) 82 final 
Fagan-Watson, B., Elliot, B., Watson, T., 2015. Lobbying by Trade Associations on EU Climate Policy.

Fankhauser, S., Hepburn, C., Park, J., 2010. Combining multiple climate policy instruments: How not to do it. Clim. Chang. Econ. 1, 209-225.

Fitch-Roy, O.W.F., 2017. Negotiating the EU's 2030 climate and energy framework: agendas, ideas and European interest groups. University of Exeter.

Flanagan, K., Uyarra, E., Laranja, M., 2011. Reconceptualising the "policy mix" for innovation. Res. Policy 40, 702-713. https://doi.org/10.1016/j.respol.2011.02.005

Foxon, T.J., 2013. Transition pathways for a UK low carbon electricity future. Energy Policy 52, 10-24. https://doi.org/10.1016/j.enpol.2012.04.001

Franceschini, S., Alkemade, F., 2016. Non-disruptive regime changes-The case of competing energy efficient lighting trajectories. Environ. Innov. Soc. Transitions 21, 56-68. https://doi.org/10.1016/j.eist.2016.04.003

French, R.M., 1969. Effectiveness of the Various Techniques Employed in the Study of Community Power. J. Polit. 31, 818-820.

Funcke, S., Bauknecht, D., 2016. Typology of centralised and decentralised visions for electricity infrastructure. Util. Policy 40, 2-9. https://doi.org/10.1016/j.jup.2016.03.005

Geels, F.W., 2004. From sectoral systems of innovation to socio-technical systems: Insights about dynamics and change from sociology and institutional theory. Res. Policy 33, 897-920. https://doi.org/10.1016/j.respol.2004.01.015

Geels, F.W., Kern, F., Fuchs, G., Hinderer, N., Kungl, G., Mylan, J., Neukirch, M., Wassermann, S., 2016. The enactment of socio-technical transition pathways: A reformulated typology and a comparative multi-level analysis of the German and UK low-carbon electricity transitions (1990-2014). Res. Policy 45, 896-913. https://doi.org/10.1016/j.respol.2016.01.015

Geels, F.W., Schot, J., 2007. Typology of sociotechnical transition pathways. Res. Policy 36, 399-417. https://doi.org/10.1016/j.respol.2007.01.003

Geels, F.W., Verhees, B., 2011. Cultural legitimacy and framing struggles in innovation journeys: A cultural-performative perspective and a case study of Dutch nuclear energy (1945-1986). Technol. Forecast. Soc. Change 78, 910 930. https://doi.org/10.1016/j.techfore.2010.12.004

Geels, I.F.W., 2005. The dynamics of transitions in socio-technical systems: A multi-level analysis of the transition pathway from horse-drawn carriages to automobiles (1860-1930). Technol. Anal. Strateg. Manag. 17, 445-476. https: / /doi.org/10.1080/09537320500357319

Girod, B., 2016. Product-oriented climate policy: learning from the past to shape the future. J. Clean. Prod. 128, 209-220. https://doi.org/10.1016/j.jclepro.2015.07.010

Glachant, J.M., Ruester, S., 2014. The EU internal electricity market: Done forever? Util. Policy 31, 221-228.

https://doi.org/10.1016/j.jup.2014.03.006

Goulder, L.H., 2013. Markets for Pollution Allowances: What Are the (New) Lessons? J. Econ. Perspect. 27, 87-102. 
https://doi.org/10.1257/jep.27.1.87

Gullberg, A.T., 2013. Lobbying for renewable energy targets in the European Union. Rev. Policy Res. 30, 611-628. https://doi.org/10.1111/ropr.12049

Görlach, B., Duwe, M., Evans, N., 2017. Frameworks for regional co-operation: The EU, in: Handbook of Transitions to Energy and Climate Security. Routledge, New York, pp. 79-96.

Haley, B., 2017. Designing the public sector to promote sustainability transitions: Institutional principles and a case study of ARPA-E. Environ. Innov. Soc. Transitions 25, 107-121. https://doi.org/10.1016/j.eist.2017.01.002

Hess, D.J., 2015. The politics of niche-regime conflicts: Distributed solar energy in the United States. Environ. Innov. Soc. Transitions 1-9. https://doi.org/10.1016/j.eist.2015.09.002

Hess, D.J., 2014. Sustainability transitions: A political coalition perspective. Res. Policy 43, 278-283. https://doi.org/10.1016/j.respol.2013.10.008

Hoppmann, J., Huenteler, J., Girod, B., 2014. Compulsive policy-making - The evolution of the German feed-in tariff system for solar photovoltaic power. Res. Policy 43, 1422-1441. https://doi.org/10.1016/j.respol.2014.01.014

Howlett, M., Rayner, J., 2013. Patching vs Packaging in Policy Formulation: Assessing Policy Portfolio Design. Polit. Gov. 1, 170-182. https://doi.org/10.12924/pag2013.01020170

Howlett, M., Rayner, J., 2007. Design Principles for Policy Mixes: Cohesion and Coherence in "New Governance Arrangements." Policy Soc. 26, 1-18. https://doi.org/http://dx.doi.org/10.1016/S1449-4035(07)70118-2

IEA, 2014. Energy Policies of IEA countries: European Union. Paris.

IPCC, 2014. Climate Change 2014: Mitigation of Climate Change: Working Group III Contribution to the Fifth Assessment Report of the Intergovernmental Panel on Climate Change. Cambridge University Press, Cambridge, United Kingdom and New York, NY, USA.

Jacobsson, S., Bergek, A., 2011. Innovation system analyses and sustainability transitions: Contributions and suggestions for research. Environ. Innov. Soc. Transitions 1, 41-57. https://doi.org/10.1016/j.eist.2011.04.006

Jamasb, T., Pollitt, M., 2005. Electricity Market Reform in the European Union : Review of Progress toward Liberalization \& Integration Authors ( s ): Tooraj Jamasb and Michael Pollitt Source: The Energy Journal , Vol . 26, Special Issue : European Electricity Liberalisation Publishe. Energy J. 26, 11-41.

Jarke, J., Perino, G., 2017. Do Renewable Energy Policies Reduce Carbon Emissions? On Caps and Inter-Industry Leakage. J. Environ. Econ. Manage. 84, 1-58. https://doi.org/10.1016/j.jeem.2017.01.004

Kemp, R., Loorbach, D., 2006. Transition management: a reflexive governance approach., in: Voß, J.-P., Bauknecht, D., Kemp, R. (Eds.), Reflexive Governance for Sustainable Development. Edward Elgar, Cheltenham, UK, pp. 103-130.

Kern, F., Markard, J., 2016. Analysing energy transitions: Combining insights from transition studies and international political economy, in: Van de Graf, T., Sovacool, B.K., Gosh, A., Kern, F., Klare, M.T. (Eds.), The Palgrave Handbook of the International Political Economy of Energy. Palgrave 
Macmillan UK, pp. 291-318.

Kivimaa, P., Kern, F., 2016. Creative destruction or mere niche support? Innovation policy mixes for sustainability transitions. Res. Policy 45, $205-$ 217. https://doi.org/10.1016/j.respol.2015.09.008

Kivimaa, P., Virkamäki, V., 2014. Policy mixes, policy interplay and low carbon transitions: The case of passenger transport in Finland. Environ. Policy Gov. 24, 28-41. https://doi.org/10.1002/eet.1629

Koch, N., Fuss, S., Grosjean, G., Edenhofer, O., 2014. Causes of the EU ETS price drop: Recession, CDM, renewable policies or a bit of everything?-New evidence. Energy Policy 73, 676-685. https://doi.org/10.1016/j.enpol.2014.06.024

Konrad, K., Markard, J., Ruef, A., Truffer, B., 2012. Strategic responses to fuel cell hype and disappointment. Technol. Forecast. Soc. Change 79, 10841098. https://doi.org/10.1016/j.techfore.2011.09.008

Kungl, G., 2015. Stewards or sticklers for change? Incumbent energy providers and the politics of the German energy transition. Energy Res. Soc. Sci. 8, 13-23. https://doi.org/10.1016/j.erss.2015.04.009

Laes, E., Gorissen, L., Nevens, F., 2014. A Comparison of Energy Transition Governance in Germany, The Netherlands and the United Kingdom. Sustainability 6, 1129-1152. https://doi.org/10.3390/su6031129

Lauber, V., Jacobsson, S., 2016. The politics and economics of constructing, contesting and restricting socio-political space for renewables - The German Renewable Energy Act. Environ. Innov. Soc. Transitions 18, 147-163. https://doi.org/10.1016/j.eist.2015.06.005

Lazard, 2017. Lazard's Levelized Cost of Energy Analysis Version 11.0 [WWW Document]. 2 Nov. URL https://www.lazard.com/perspective/levelized-costof-energy-2017/

Leach, M., Stirling, A.C., Scoones, I., 2010. Dynamic Sustainabilities. Technology, Environment, Social Justice. Routledge, London.

Lilliestam, J., Hanger, S., 2016. Shades of green: Centralisation, decentralisation and controversy among European renewable electricity visions. Energy Res. Soc. Sci. 17, 20-29. https://doi.org/10.1016/j.erss.2016.03.011

Magnusson, T., Tell, F., Watson, J., 2005. From CoPS to mass production? Capabilities and innovation in power generation equipment manufacturing. Ind. Corp. Chang. 14, 1-26. https://doi.org/10.1093/icc/dth042

Markard, J., 2018. The next phase of the energy transition and its implications for research and policy. Nature Energy 3, 628-633.

Markard, J., Petersen, R., 2009. The offshore trend: Structural changes in the wind power sector. Energy Policy 37, 3545-3556.

Markard, J., Raven, R., Truffer, B., 2012. Sustainability transitions: An emerging field of research and its prospects. Res. Policy 41, 955-967. https://doi.org/10.1016/j.respol.2012.02.013

Markard, J., Suter, M., Ingold, K., 2016. Socio-technical transitions and policy change - Advocacy coalitions in Swiss energy policy. Environ. Innov. Soc. Transitions 18, 215-237. https://doi.org/10.1016/j.eist.2015.05.003

Markard, J., Truffer, B., 2006. Innovation processes in large technical systems: 
Market liberalization as a driver for radical change? Res. Policy 35, 609-625. https: / / doi.org/10.1016/j.respol.2006.02.008

Matthes, F.C., 2010. Greenhouse gas emissions trading and complementary policies: Developing a smart mix for ambitious climate policies. Nucl. Saf. 49, $1-44$.

Meadowcroft, J., 2011. Engaging with the politics of sustainability transitions. Environ. Innov. Soc. Transitions 1, 70-75. https://doi.org/10.1016/j.eist.2011.02.003

Meckling, J., 2011. The Globalization of Carbon Trading: Transnational Business Coalitions in Climate Politics. Glob. Environ. Polit. 11, 26-50. https://doi.org/10.1162/GLEP_a_00052

Mitchell, C., 2016. Momentum is increasing towards a flexible electricity system based on renewables. Nat. Energy 1, 15030. https://doi.org/10.1038/nenergy.2015.30

Mäkitie, T., Andersen, A.D., Hanson, J., Normann, H.E., Thune, T.M., 2018. Established sectors expediting clean technology industries? The Norwegian oil and gas sector's influence on offshore wind power. J. Clean. Prod. 177, 813-823. https://doi.org/10.1016/j.jclepro.2017.12.209

Raven, R., Kern, F., Smith, A., Jacobsson, S., Verhees, B., 2016. The politics of innovation spaces for low-carbon energy: Introduction to the special issue. Environ. Innov. Soc. Transitions 18, 101-110. https://doi.org/10.1016/j.eist.2015.06.008

Reichardt, K., Negro, S.O., Rogge, K.S., Hekkert, M.P., 2016. Analyzing interdependencies between policy mixes and technological innovation systems: The case of offshore wind in Germany. Technol. Forecast. Soc. Change 106, 11-21. https://doi.org/10.1016/j.techfore.2016.01.029

Reichardt, K., Rogge, K., 2016. How the policy mix impacts innovation: Findings from company case studies on offshore wind in Germany. Environ. Innov. Soc. Transitions 18, 62-81. https://doi.org/10.1016/j.eist.2015.08.001

Reid, W. V., Chen, D., Goldfarb, L., Hackmann, H., Lee, Y.T., Mokhele, K., Ostrom, E., Raivio, K., Rockstrom, J., Schellnhuber, H.J., Whyte, A., 2010. Earth System Science for Global Sustainability: Grand Challenges. Science (80-. ). 330, 916-917. https://doi.org/10.1126/science.1196263

REN21, 2017. Renewables 2017 Global Status Report. Paris. https://doi.org/10.1016/j.rser.2016.09.082

Richter, M., 2013. Business model innovation for sustainable energy: German utilities and renewable energy. Energy Policy 62, 1226-1237. https://doi.org/10.1016/j.enpol.2013.05.038

Rogge, K.S., Reichardt, K., 2016. Policy mixes for sustainability transitions: An extended concept and framework for analysis. Res. Policy 45, 1620-1635. https://doi.org/10.1016/j.respol.2016.04.004

Rosenbloom, D., 2017. Pathways: An emerging concept for the theory and governance of low-carbon transitions. Glob. Environ. Chang. 43, 37-50. https://doi.org/10.1016/j.gloenvcha.2016.12.011

Sabatier, P.A., Weible, C.M., 2007. The advocacy coalition framework: innovations and clarifications., in: Sabatier, P.A. (Ed.), Theories of the Policy Process. Westview Press, Boulder, CO., pp. 189-220. 
Scheer, H., 2006. Energy Autonomy: The Economic, Social and Technological Case for Renewable Energy. Routledge, London.

Schlaile, M.P., Urmetzer, S., Blok, V., Andersen, A.D., Timmermans, J., Mueller, M., Fagerberg, J., Pyka, A., 2017. Innovation systems for transformations towards sustainability? Taking the normative dimension seriously. Sustain. 9. https: //doi.org/10.3390/su9122253

Schmid, E., Knopf, B., Pechan, A., 2016. Putting an energy system transformation into practice: The case of the German Energiewende. Energy Res. Soc. Sci. 11, 263-275. https://doi.org/10.1016/j.erss.2015.11.002

Schmidt, T.S., Sewerin, S., 2017. Technology as a driver of climate and energy politics. Nat. Energy 2, 17084. https://doi.org/10.1038/nenergy.2017.84

Schumpeter, J., 1934. The Theory of Economic Development. Harvard University Press, Cambridge, MA.

Skjærseth, J.B., Eikeland, P.O., Gulbrandsen, L.H., Jevnaker, T., 2016. Linking EU Climate and Energy Policies: Decision-making, Implementation and Reform. Edward Elgar, Cheltenham, UK.

Smink, M.M., Hekkert, M.P., Negro, S.O., 2015. Keeping sustainable innovation on a leash? Exploring incumbents' institutional strategies. Bus. Strateg. Environ. 24, 86-101. https://doi.org/10.1002/bse.1808

Smith, A., Raven, R., 2012. What is protective space? Reconsidering niches in transitions to sustainability. Res. Policy 41, 1025-1036. https://doi.org/10.1016/j.respol.2011.12.012

Smith, A., Stirling, A., 2010. The Politics of Social-ecological Resilience and Sustainable Socio- technical Transitions. Ecol. Soc. 15, 11. https: / / doi.org/ 10.5751/ES-04565-170208

Smith, A., Stirling, A., Berkhout, F., 2005. The governance of sustainable sociotechnical transitions. Res. Policy 34, 1491-1510. https://doi.org/10.1016/j.respol.2005.07.005

Stirling, A., 2014. Transforming power: Social science and the politics of energy choices. Energy Res. Soc. Sci. 1, 83-95. https://doi.org/10.1016/j.erss.2014.02.001

Strunz, S., 2014. The German energy transition as a regime shift. Ecol. Econ. 100, 150-158. https://doi.org/10.1016/j.ecolecon.2014.01.019

United Nations Environment Programme (UNEP), 2016. The Emissions Gap Report 2016, United Nations Environment Program. https://doi.org/ISBN 978-92-807-3617-5

Van den Berg, K., Delarue, E., D'haeseleer, W., 2013. Impact of renewables deployment on the $\mathrm{CO} 2$ price and the $\mathrm{CO} 2$ emissions in the European electricity sector. Energy Policy 63, 1021-1031.

Verbong, G.P.J., Geels, F.W., 2010. Exploring sustainability transitions in the electricity sector with socio-technical pathways. Technol. Forecast. Soc. Change 77, 1214-1221. https://doi.org/10.1016/j.techfore.2010.04.008

Verbruggen, A., Lauber, V., 2012. Assessing the performance of renewable electricity support instruments. Energy Policy 45, 635-644. https://doi.org/10.1016/j.enpol.2012.03.014

Wesseling, J.H., Farla, J.C.M., Sperling, D., Hekkert, M.P., 2014. Car 
manufacturers' changing political strategies on the ZEV mandate. Transp.

Res. Part D Transp. Environ. 33, 196-209.

https://doi.org/10.1016/j.trd.2014.06.006

Wittneben, B.B.F., 2012. The impact of the Fukushima nuclear accident on

European energy policy. Environ. Sci. Policy 15, 1-3.

https: / /doi.org/10.1016/j.envsci.2011.09.002

Ydersbond, I.M., 2016. Where is power really situated in the EU ? Complex multistakeholder negotiations and the climate and energy 2030 targets. FNI report 3/2016. Fridtjof Nansen Institute. Oslo. 


\section{Annex}

Table A1: Example of policy types in the coding scheme

\begin{tabular}{|l|l|l|}
\hline Policy & Assessment & Scaling \\
\hline PCI 2013 & $\begin{array}{l}\text { The PCI } 2013 \text { describes the conditions for infrastructure } \\
\text { projects being eligible for financial support from the EU. It } \\
\text { highlights the need for interconnectors in order to facilitate } \\
\text { renewable electricity in the system. Simultaneously, it also } \\
\text { defines the criteria for support to gas and CCS infrastructure. If } \\
\text { a large share of EU funding is granted to projects for fossil } \\
\text { infrastructure, there will be less available to develop the } \\
\text { solutions facilitating RES. }\end{array}$ & $\begin{array}{l}\text { "priority gas corridors" = 1 on } \\
\text { the RES scale (weighted 1) }\end{array}$ \\
\hline SAG 2014 & $\begin{array}{l}\text { Competitive bidding for RES support is included since this is } \\
\text { the new obligation for RES support schemes in the State Aid } \\
\text { Guidelines (SAG 2014). From 2017 onwards, RES support must } \\
\text { be granted in competitive bidding, with exemptions for small- } \\
\text { scale generators <550kW. Since competitive bidding and } \\
\text { auctioning involves costly preparations for bidders like } \\
\text { establishing up-front funding and developing bankable project } \\
\text { descriptions, it favors larger, established actors. We therefore } \\
\text { define it as favoring centralization. }\end{array}$ & $\begin{array}{l}\text { Competitive bidding = 1 on DEC } \\
\text { scale (weighted 2) }\end{array}$ \\
(weighted 1) 3 on DEC scale \\
\hline
\end{tabular}

Table A2: Example of assessing potential impact for EMD 2009

\begin{tabular}{|l|l|}
$\begin{array}{l}\text { Source: } \\
\text { Mectricity } \\
\text { Directive }\end{array}$ & $\begin{array}{l}\text { Chapter III: Generation } \\
\text { Article 7: Authorisation procedure for new capacity } \\
\text { generating capacity in their territory. In determining appropriate criteria, Member States shall } \\
\text { consider: }\end{array}$ \\
$\begin{array}{l}\text { (j) the contribution of the generating capacity to meeting the overall Community target of at least a } \\
\text { 20\% share of energy from renewable sources in the Community's gross final consumption of energy } \\
\text { in } 2020 \text { referred to in Article 3(1) of Directive 2009/28/EC of the European Parliament and of the } \\
\text { Council of 23 April 2009 on the promotion of the use of energy from renewable sources, and; } \\
\text { (k) the contribution of generating capacity to reducing emissions. }\end{array}$ \\
\hline Ranking & $\begin{array}{l}\text { It is a prescription for MSs to consider the renewable and emissions reduction target when granting } \\
\text { authorization for new generation capacity. It promotes renewables, since MSs must consider the } \\
\text { targets in their procedures; however, it is not strongly stating the need to achieve the targets. Hence } \\
\text { it is ranked 3 = We need to increase RES shares, and make sure we have some targets for RES. }\end{array}$ \\
\hline Weighting & $\begin{array}{l}\text { This is a prescription for all MSs, but it is not of major importance. It is also not the main instrument } \\
\text { in the Electricity Market Directive. It is hence weighted 1. }\end{array}$ \\
\hline
\end{tabular}


Table A3: Example of coding in excel - the coding of the PCI 2013

\begin{tabular}{|c|c|c|c|c|c|c|}
\hline Dimensions & Sub-dimensions & Activated categories (policy text in comments) & Policy element & Value & Weight & $\begin{array}{l}\text { Value * } \\
\text { Weigth }\end{array}$ \\
\hline \multirow[t]{19}{*}{ (De)centralized } & 1.1 Decentralized generation & & & & & \\
\hline & 1.2 Grid fees & & & & & \\
\hline & 1.3 Market integration of RES & & & & & \\
\hline & 1.4 Prosumerism & & & & & \\
\hline & 1.5 Demand Side Management & Deployment of smart grids & Strategy & 4 & 0,5 & 2 \\
\hline & & Importance of smart grids & Strategy/Restate pol. target & 4 & 1 & 4 \\
\hline & & Smart Grid PCl & Instrument & 3 & 0,5 & 1,5 \\
\hline & & Priority thematic areas - smart grids & Instrument & 3 & 0,5 & 1,5 \\
\hline & 1.6 Storage & & & & & \\
\hline & 1.7 Interconnectors & Need to upgrade and interconnect energy networks & Strategy & 1 & 1 & 1 \\
\hline & & 2002 target: $10 \%$ electricity interconnections & Strategy/Restate pol. target & 1 & 2 & 2 \\
\hline & & Integration between national networks & Strategy & 1 & 1 & 1 \\
\hline & & Rules for timely development and interoperability of networks & Instrument & 1 & 2 & 2 \\
\hline & & Priority electricity corridors & Instrument & 1 & 2 & 2 \\
\hline & 1.8 Capacity Markets & & & & & \\
\hline & 1.9 System Operation & & & & & \\
\hline & 1.10 ETS should be main policy & & & & & \\
\hline & 1.11 Competitive bidding RES support & & & & & \\
\hline & Sum & & & & 10,5 & 17 \\
\hline \multirow[t]{16}{*}{ Renewable Energy } & 2.1 RES deployment & Energy infrastructure necessary for sustainability targets & Strategy/Restate pol. target & 3 & 0,5 & 1,5 \\
\hline & & Develop renewable energy sources in competition with traditional sources & Strategy/Restate pol. target & 2 & 0,5 & 1 \\
\hline & 2.2 RES potential & & & & & \\
\hline & 2.3 RES targets & & & & & \\
\hline & 2.4 RES leads to increased system costs & & & & & \\
\hline & 2.5 RES support & & & & & \\
\hline & 2.6 MSs must develop grids for RES & & & & & \\
\hline & 2.7 Integrate RES into power system & Need to upgrade energy networks and integrate RES & Strategy & 4 & 0,5 & 2 \\
\hline & & PCls should contribute to sustainability or market int. or SS & Instrument & 2 & 2 & 4 \\
\hline & & Priority thematic areas - electricity highways & Instrument & 3 & 1 & 3 \\
\hline & & Infrastructure is vital to achieve energy and climate object. & Strategy/Restate pol. target & 4 & 0,5 & 2 \\
\hline & & Prepare infrastructure for further decarb. towards 2050 & Strategy & 4 & 0,5 & 2 \\
\hline & & Stability of el network & Strategy & 3 & 0,5 & 1,5 \\
\hline & 2.8 Support fossil / nuclear technology & Priority thematic areas - gas corridors & Instrument & 1 & 1 & 1 \\
\hline & Sum & & & & 7 & 18 \\
\hline & DEC & RES & & & & \\
\hline Strategies & 3 & 3,3 & & & & \\
\hline Instruments & 3 & 2,0 & & & & \\
\hline Aggregated S\&I & 1,6 & 2,6 & & & & \\
\hline
\end{tabular}


Table A4: The coding values of actors

\begin{tabular}{|c|c|c|c|c|}
\hline Number & Actors & Full Name & DEC & RES \\
\hline 1 & Foratom & & 1,25 & 1,83 \\
\hline 2 & EURELECTRIC & & 1,33 & 2,45 \\
\hline 3 & Business Europe & & 1,42 & 1,33 \\
\hline 4 & Euracoal & The European Association for Coal and Lignite & 1,42 & 1,11 \\
\hline 5 & EDF & Electricite de France & 1,64 & 2,65 \\
\hline 6 & Iberdrola & & 1,75 & 2,88 \\
\hline 7 & ERDF & Electricite Reseau Distribution France & 1,75 & 3,06 \\
\hline 8 & Statkraft & & 1,75 & 2,84 \\
\hline 9 & ACER & & 1,77 & 2,63 \\
\hline 10 & IEA & International Energy Agency & 1,84 & 3,13 \\
\hline 11 & EFET & European Federation of Energy Traders & 1,92 & 2,25 \\
\hline 12 & Entso-E & European Network of Transmission System Operators for Electricity & 1,93 & 3,18 \\
\hline 13 & Cefic & European Chemical Industry Council & 1,96 & 1,88 \\
\hline 14 & RWE & & 2,04 & 3,04 \\
\hline 15 & E.ON & & 2,10 & 2,75 \\
\hline 16 & Enel & & 2,25 & 2,83 \\
\hline 17 & Eurochambers & The Association of European Chambers of Commerce and Industry & 2,25 & 2,50 \\
\hline 18 & EDSO & European Distribution System Operators' Association for Smart Grids & 2,25 & 2,82 \\
\hline 19 & Europex & Association of European Energy Exchanges & 2,25 & 2,67 \\
\hline 20 & General Electric & & 2,30 & 3,36 \\
\hline 21 & Ease & European Association for Storage of Energy & 2,40 & 2,89 \\
\hline 22 & Dong & & 2,50 & 3,33 \\
\hline 23 & IFIEC & International Federation of Industrial Energy Consumers & 2,54 & 1,46 \\
\hline 24 & EWEA & European Wind Energy Association & 2,64 & 2,38 \\
\hline 25 & CEDEC & European Federation of Local Energy Companies & 2,72 & 3,64 \\
\hline 26 & Alstom & & 2,78 & 3,00 \\
\hline 27 & TenneT & & 2,64 & 2,38 \\
\hline 28 & SEDC & Smart Energy Demand Coalition & 2,80 & 3,35 \\
\hline 29 & Total & & 2,98 & 3,36 \\
\hline 30 & Euroheat and power & & 3,03 & 2,67 \\
\hline 31 & Solar Power Europe & & 3,12 & 3,85 \\
\hline 32 & WWF & World Wildlife Foundation & 3,12 & 3,95 \\
\hline 33 & EREF & European Renewable Energies Federation & 3,32 & 3,74 \\
\hline 34 & BEE & German renewable energy association & 3,41 & 3,63 \\
\hline 35 & E3G & Third Generation Environmentalism & 3,42 & 3,50 \\
\hline 36 & Greenpeace & & 3,60 & 4,00 \\
\hline 37 & CAN & Climate Action Network & 3,80 & 3,92 \\
\hline
\end{tabular}


Table A5: List of interviewees. All interviewees are Brussels-based.

\begin{tabular}{|l|l|l|}
\hline Number & Position & Organisation \\
\hline 11 & Head of European Affairs & Transmission System Operator \\
\hline 12 & Manager, Senior Advisor & Electricity Association \\
\hline 13 & $\begin{array}{l}\text { Senior Policy Officer, two Policy } \\
\text { Officers }\end{array}$ & European Commission \\
\hline 14 & Senior Analyst & Renewable energy association \\
\hline 15 & Policy Officer & European Commission \\
\hline 16 & Senior Policy Officer & European Commission \\
\hline 17 & Policy Advisor & Renewable energy association \\
\hline
\end{tabular}

Table A6: Interview guide. All interviews were carried out, transcribed and analyzed by the first author.

\section{Semi-structured interview guide}

In the interview, I will ask you about a) challenges for electricity sector, b) RES support/policies

c) The issue of centralization versus decentralization of the electricity system and d) the policy process.

\section{EU energy and climate policy - general perspectives}

a. The electricity sector is changing rapidly, both in Europe and worldwide. What are the greatest challenges for the electricity system in Europe?

b. How is existing EU legislation suited to meet these challenges?

c. What are the most important policies for the electricity sector?

2. Renewable energy deployment We operate with a renewable energy dimension where we distinguish between four different levels of ambition:

\begin{tabular}{|l|l|}
\hline Scales & Renewable ambition - POLICIES \\
\hline 1 & Stop further renewable energy deployment. \\
\hline 2 & Renewable energy can be deployed in some areas, but without support \\
\hline 3 & Ensure further growth in renewable energy shares \\
\hline 4 & Ensure a transition to a 100\% RES system \\
\hline
\end{tabular}

a. How ambitious are European renewable energy targets on a scale from 1 to 4 ?

b. With respect to these scales, where would you allocate the European policies?

c. Are the policies sufficient in order to achieve the targets?

d. What are challenges for further RES deployment?

i. How are these challenges related to current policies?

ii. To what extent is the Clean Energy Package suited to deal with these issues?

3. Decentralization versus centralization (Please note: decentralization in the sense of the technical configuration of the electricity system, not governance. High decentralization means high share of decentralized power generation)

a. The issue of decentralization versus centralization of the energy system is of high importance. The e-sector can go highly centralized but also become much more decentralized. What are the major challenges in this respect? 


\begin{tabular}{|c|c|}
\hline & $\begin{array}{l}\text { b. How important is the discussion about decentralization versus centralization } \\
\text { within EU energy policy? } \\
\text { c. How important have current EU policies been in this respect? Do they tend to } \\
\text { pull the system in one direction or the other? (If helpful, use the scales below:) }\end{array}$ \\
\hline Scales & Decentralization versus centralization - POLICIES \\
\hline 1 & Strongly prefer and support centralized options \\
\hline 2 & Some preference and support for centralized options \\
\hline 3 & Some preference and support for decentralized options \\
\hline 4 & Strongly prefer and support decentralized options \\
\hline
\end{tabular}

4. Policy interaction

a. A key issue in the policy debate is the interaction between two or several policies. What would you consider the most important interactions between the main policies in the electricity sector? (i.e. synergies and detrimental effects between directives, regulations and guidelines)

b. Were these interactions expected or did they appear unexpected to regulators and policy makers?

5. Flexibility (in the sense of technologies and measures that increase the flexibility of the power system. Includes measures for a flexible operation of the market as well as the physical flexibility options - grids, storage, DSM etc.)

a. There are diverging views on flexibility. For instance, the German Government writes in their submission to the NEM consultation that 'The potential of flexibility options is manyfold (gas power plants, flexible consumers, storage) and larger than the actual need. What are your perspectives on this?

b. How can EU policies facilitate for more flexibility? New market design, technology development, R\&D?

c. What are preferred flexibility options until 2030 - and until 2050?

d. What role do you expect DSM to play in this regard?

e. Do you think there is sufficient incentive in the WP to enhance DSM? Or are there other policies that will be decisive in this respect?

f. Do you consider that different flexibility options, for example DSM and interconnectors (and maybe even capacity markets), stand in competition to each other, or do they rather complement each other? 